\title{
RELIGIOUS NEUTRALITY IN THE EARLY REPUBLIC
}

\author{
Wesley J. Campbell*
}

\begin{abstract}
Governmental neutrality is the heart of the modern Free Exercise Clause. Mindful of this core principle, which prevents the government from treating individuals differently because of their religious convictions, the Supreme Court held in Employment Division v. Smith that a neutral law can be constitutionally applied despite any incidental burdens it might impose on an individual's exercise of religion. Conscientious objectors such as Quakers, for instance, do not have a constitutional right to be exempt from a military draft. Thus, neutrality now forms both the core and the outer limit of constitutionally guaranteed religious freedom. Judged according to founding-era views, however, this interpretation of the Free Exercise Clause is deeply problematic. Although historical scholarship has focused on the particular issue of religious exemptions, this Article takes a different approach by reexamining early debates about neutrality itself. These neglected sources demonstrate that modern cases invert the foundingera conception of religious freedom. For the Founders, religious freedom was primarily an unalienable natural right to practice religion-not a right that depended on whether a law was neutral. This evidence illuminates not only a significant transition in constitutional meaning since the Founding but also the extent to which modern priorities often color our understanding of the past.
\end{abstract}

TABLE OF CONTENTS

INTRODUCTION

312

I. Two THEORIES OF RELIGIOUS FreEDOM ……....................................... 317

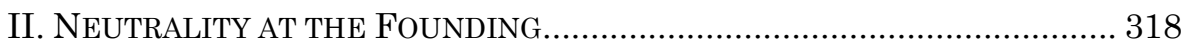

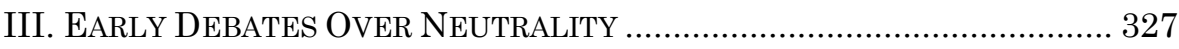

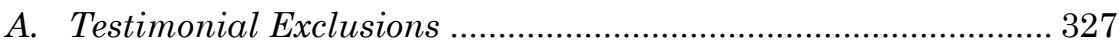

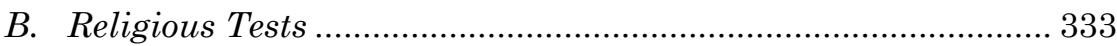

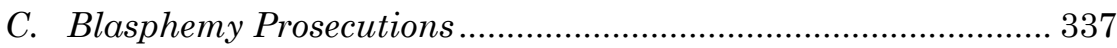

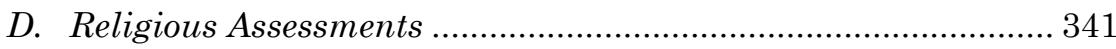

E. The 1821 New York Convention ................................................. 343

* Law Clerk to the Honorable Diane S. Sykes, United States Court of Appeals for the Seventh Circuit; J.D., Stanford Law School, 2011; B.A., University of North Carolina at Chapel Hill, 2006. The author thanks Mike McConnell, Alex Gesch, Daniel Suhr, Jay Schweikert, and the editors of the Regent University Law Review for their helpful suggestions. The views expressed in this Article, of course, are the author's own. 


\section{INTRODUCTION}

The core of our modern understanding of religious freedom is governmental neutrality - a principle that generally forbids the government from treating people differently on the basis of their religious beliefs. ${ }^{1}$ In Sherbert $v$. Verner, for example, the Supreme Court declared that "[t]he door of the Free Exercise Clause stands tightly closed against any governmental regulation of religious beliefs as such." ${ }^{2}$ Any law that "establishes a religious classification" 3 is therefore unconstitutional even if the law neither infringes upon a person's practice of religion nor deprives the individual of a civil right. ${ }^{4}$ Based on this principle, the Supreme Court has held that the federal and state governments may not discriminate against particular religious groups, ${ }^{5}$ prevent clergy from serving in civil offices, ${ }^{6}$ or bar atheists from becoming notaries public. ${ }^{7}$ The same neutrality requirement also applies even if the law is "rewarding religious beliefs as such."

While considering neutrality as the core principle of religious freedom, the Supreme Court has also evaluated whether facially neutral

1 This definition of religious neutrality follows the holdings of modern free exercise decisions. See infra note 4. Some scholars have posited other meanings of neutrality. Douglas Laycock, Formal, Substantive, and Disaggregated Neutrality Toward Religion, 39 DEPAUL L. REV. 993, 994 (1990).

2374 U.S. 398, 402 (1963); see also Church of the Lukumi Babalu Aye, Inc. v. City of Hialeah, 508 U.S. 520, 533 (1993) (“[A] law targeting religious beliefs as such is never permissible....").

3 McDaniel v. Paty, 435 U.S. 618, 631-32 (1978) (Brennan, J., concurring) ("Whether or not the provision discriminates among religions . . . it establishes a religious classification ....").

4 See, e.g., id. at 633 ("[T] it does not directly prohibit religious activity, but merely conditions eligibility for office on its abandonment-is also squarely rejected by precedent."); Torcaso v. Watkins, 367 U.S. 488, 495-96 (1961) ("The fact . . that a person is not compelled to hold public office cannot possibly be an excuse for barring him from office by state-imposed criteria forbidden by the Constitution."). One decision potentially in conflict with a neutrality-based view is Locke $v$. Davey, 540 U.S. 712, 725 (2004), which rejected a free-exercise challenge to a state's denial of a government-funded vocational scholarship that an individual wished to use to fund religious training in preparation for a career in the ministry. In Locke, the majority found it significant that the State had conditioned the receipt of funds on the student's choice of vocation, which the Court considered as distinct from the student's religious beliefs. Id. at 720-21 ("And it does not require students to choose between their religious beliefs and receiving a government benefit. The State has merely chosen not to fund a distinct category of instruction." (footnote and citations omitted)).

5 Fowler v. Rhode Island, 345 U.S. 67, 69-70 (1953).

6 McDaniel, 435 U.S. at 628-29 (plurality opinion).

7 Torcaso, 367 U.S. at 489, 495.

8 McDaniel, 435 U.S. at 626 (plurality opinion) (emphasis added). 
laws violate the Free Exercise Clause when their enforcement incidentally interferes with an individual's religious beliefs or practices. In the decades prior to 1990, the Supreme Court held that "[a] regulation neutral on its face may, in its application, nonetheless offend the constitutional requirement for governmental neutrality if it unduly burdens the free exercise of religion." 9 In other words, a law ostensibly having nothing to do with religion (such as a military draft) could nonetheless unconstitutionally burden the free exercise rights of particular individuals (such as conscientious objectors). In these instances, the Court formerly applied strict scrutiny and required the government to prove a compelling interest for infringing upon an individual's religious practice. ${ }^{10}$ In taking this position, the Court explained that not applying strict scrutiny to neutral infringements upon the individual right to free exercise would "relegate[ a serious First Amendment value to the barest level of minimal scrutiny that the Equal Protection Clause already provides."11

In Employment Division v. Smith, however, the Supreme Court shifted course, holding that the Free Exercise Clause does not provide an individual right of religious exemption from facially neutral laws. ${ }^{12}$ In particular, the five-Justice majority decided that states can enforce their controlled substance laws against Native Americans who use hallucinogenic drugs as part of their sacramental practices. ${ }^{13}$ The government still may not discriminate under the guise of facially neutral laws, but following Smith, the constitutional inquiry centers on the governmental action-not the law's effect on individuals. ${ }^{14}$ In other words, governmental neutrality now is not just the core of constitutionally protected religious liberty; it also marks the outer boundary.

9 Wisconsin v. Yoder, 406 U.S. 205, 220 (1972).

10 Hobbie v. Unemp't Appeals Comm'n, 480 U.S. 136, 141 (1987).

11 Id. at 141-42 (quoting Bowen v. Roy, 476 U.S. 693, 727 (1986) (O'Connor, J., concurring)) (internal quotation marks omitted).

12494 U.S. 872, 878-79, 890 (1990).

13 Id. at 873-74, 890. Justice O'Connor filed a separate concurring opinion criticizing the majority's departure from "established free exercise jurisprudence," but she agreed that Oregon could prohibit the religious use of peyote because she thought the law survived heightened scrutiny under existing doctrine. Id. at 902, 907 (O'Connor, J., concurring).

14 See Church of the Lukumi Babalu Aye, Inc. v. City of Hialeah, 508 U.S. 520, 534 (1993) ("Official action that targets religious conduct for distinctive treatment cannot be shielded by mere compliance with the requirement of facial neutrality. The Free Exercise Clause protects against governmental hostility which is masked as well as overt.”). In these instances, it is critical to realize that the constitutional infirmity-at least according to the Court-is not the effect of the law on individuals. Rather, the government's effort to target those individuals is what offends the First Amendment. Id. 
With the rise of originalism jurisprudence, historical evidence has played a significant role in modern debates about how to interpret the Free Exercise Clause. Because it is now accepted that the government may not discriminate on the basis of religion, these debates have generally focused on the question presented in Smith: whether the Free Exercise Clause provides an individual right of religious exemption from neutral, generally applicable laws. ${ }^{15}$ In City of Boerne v. Flores, ${ }^{16}$ for example, Justice Scalia's concurrence and Justice O'Connor's dissent wrangled over whether Smith was consistent with the original meaning of the Free Exercise Clause. ${ }^{17}$ Historical arguments have also been featured prominently in discussions among academic scholars. Michael McConnell writes that the "doctrine of free exercise exemptions is more consistent with the original understanding than is a position that leads only to the facial neutrality of legislation." 18 Others vigorously dispute that claim. Philip Hamburger, for instance, argues that "late eighteenthcentury Americans tended to assume that the Free Exercise Clause did not provide a constitutional right of religious exemption from civil laws." 19 Neither position has garnered scholarly consensus, in part because founding-era debates about exemptions were often mired in uncertainty. ${ }^{20}$ Nonetheless, scholarly debates about religious freedom

15 See Smith, 494 U.S. at 874.

16521 U.S. 507 (1997).

17 Id. at 537-38 (Scalia, J., concurring); id. at 544-45 (O'Connor, J., dissenting).

18 Michael W. McConnell, The Origins and Historical Understanding of Free Exercise of Religion, 103 HARV. L. REV. 1409, 1512 (1990) [hereinafter McConnell, Origins]; see also Walter J. Walsh, The First Free Exercise Case, 73 GEO. WASH. L. REV. 1, 39-40 (2004) (arguing that early state free exercise decisions support religious exemptions).

19 Philip A. Hamburger, A Constitutional Right of Religious Exemption: An Historical Perspective, 60 GEO. WASH. L. REV. 915, 916 (1992) [hereinafter Hamburger, Religious Exemption]; see also Gerard V. Bradley, Beguiled: Free Exercise Exemptions and the Siren Song of Liberalism, 20 HoFSTRA L. REV. 245, 247-48 (1991) (arguing on historical grounds against religious exemptions); see also Ellis M. West, The Right to Religion-Based Exemptions in Early America: The Case of Conscientious Objectors to Conscription, 10 J.L. \& RELIGION 367, 370-71 (1993-1994).

20 Several factors account for the indeterminacy of nineteenth-century religious exemption cases. First, eighteenth-century and early nineteenth-century views about theology, evidence rules, and judicial review differed dramatically from our own, thus limiting our ability to glean constitutional meaning out of these early cases. Wesley J. Campbell, Note, A New Approach to Nineteenth-Century Religious Exemption Cases, 63 STAN. L. REV. 973, 976 (2011). Moreover, early jurists may have applied something akin to our modern "compelling governmental interest" test whereby a compelling governmental interest can be sufficient to override a person's individual liberty claim. See Michael W. McConnell, Freedom from Persecution or Protection of the Rights of Conscience?: A Critique of Justice Scalia's Historical Arguments in City of Boerne v. Flores, 39 WM. \& MARY L. REV. 819, 845-46 (1998) [hereinafter McConnell, Freedom from Persecution] ("The most persuasive interpretation of the state precursors of the Free Exercise Clause, therefore, is that they provided substantive protection for religious conduct, except for acts that violate the peace and safety of the state or the rights of others."). Thus, it is often difficult when 
remain active, and the Court continues to wrestle with the often uncomfortable implications of its Smith decision. ${ }^{21}$

Historical studies by legal scholars have focused almost exclusively on early American debates about exemptions and ignored debates about neutrality. McConnell, for instance, acknowledges that most early nineteenth-century religious-freedom cases involved witnesses excluded from testifying because of their faith, or prosecutions for blasphemous statements, but he does not discuss these cases because they "involved laws specifically directed at religion" and therefore "did not raise the exemption question." 22 The scholarly focus on exemption cases is perfectly natural, of course, but it also has led scholars to overlook a wealth of historical materials not directly related to exemption debates but nonetheless integral to understanding how the Founders thought about religious freedom. In particular, debates concerning religious neutrality oftentimes better reveal the values and priorities implicit in founding-era understandings of free exercise.

Only one scholar has examined how these early debates about neutrality bear on the exemption question. In an important historical analysis of religious exemptions, Gerard Bradley persuasively demonstrates that courts were historically unwilling to overturn laws that facially discriminated on the basis of religious belief. ${ }^{23}$ Bradley then pounces on McConnell's dismissal of religious neutrality cases as unconnected to the exemption debate by stating, "[O]ne has to wonder about the coherence of [McConnell's] project: courts would enforce laws 'specifically directed at religion' (and thus intentionally coerce belief), but not laws that pursued secular goals incidentally burdening belief." 24 With such indifference toward religious neutrality, Bradley argues, judges surely were unwilling to provide exemptions from neutral laws. ${ }^{25}$

reading early cases to discern whether jurists rejected the possibility of exemptions generally, or instead thought an exemption was not warranted in the context of particular cases notwithstanding constitutional protection for other exemptions.

21 See, e.g., Hosanna-Tabor Evangelical Lutheran Church \& Sch. v. EEOC, 132 S. Ct. 694, 706-07 (2012) (addressing whether and to what extent the First Amendment affords religious institutions constitutional exemptions from certain employment laws).

22 McConnell, Origins, supra note 18, at 1503.

23 Bradley, supra note 19, at 271-72, 275-76, 285.

$24 I d$. at 274. Bradley argues that blasphemy and testimonial exclusion cases were not "directed at religion" but rather aimed at the religiously neutral goals of protecting public safety and ensuring testimonial veracity. $I d$. at 274-77. He clarifies, however, that " $[\mathrm{t}$ ]o the extent that the cases are 'directed at religion,' their significance cuts deeply into McConnell's case." Id. at 277. Under modern neutrality principles, these laws would be "directed at religion," irrespective of whether the government was pursuing a neutral goal. See supra note 4.

25 See id. at 275. 
Although perhaps counterintuitive, early judicial enforcement of facially discriminatory laws actually supports the historical argument for religious exemptions. State governments during the Founding Era generally accommodated minority religious practices while simultaneously restricting certain civil privileges on the basis of religious belief.26 When considering the consistency of these discriminatory laws with constitutionally protected religious liberty, late eighteenth-century and early nineteenth-century judges, legislators, and other legal commentators frequently noted that governmental classifications were legitimate so long as they did not infringe upon a person's free exercise. By putting aside our modern priorities and rereading these debates on their own terms, the original meaning of the First Amendment becomes much clearer: The Free Exercise Clause guaranteed a natural, unalienable right of religious freedom - not a right to governmental neutrality.

This Article argues that in order to understand the Founders' views regarding religious exemptions, we must first understand how they thought about religious liberty more generally and how much that viewpoint differs from our own. Part I lays the theoretical groundwork of the paper by describing two theories of religious freedom: the governmental neutrality approach and the individual liberty approach. Early state and federal constitutional provisions concerning religious freedom are presented in Part II, which analyzes the values and priorities underlying those provisions. Part III then discusses judicial decisions and other early nineteenth-century debates about religious neutrality. In particular, this Part analyzes neglected evidence from testimonial exclusion cases, test oath debates, blasphemy prosecutions, and religious assessment controversies. As argued in Part IV, nineteenth-century perspectives regarding religious neutrality are an under-utilized yet remarkably revealing source for understanding the original public meaning of the Free Exercise Clause. The Article does not take a normative position about how much this historical meaning should matter in modern jurisprudence, and it certainly does not aim to undercut modern neutrality jurisprudence. ${ }^{27}$ To those who factor original meaning into their constitutional calculus, however, historical evidence casts doubt on the Supreme Court's current refusal to recognize the

26 See infra Part III.

27 The proper home for neutrality values, however, may be elsewhere in the Constitution, particularly in the Establishment Clause and the Equal Protection Clause. Rather than attack neutrality principles, this Article argues that the Court's current focus on neutrality tends to warp its understanding of original free-exercise principles. 
constitutional underpinnings of an individual right to religious accommodation. ${ }^{28}$

\section{Two THEORIES OF RELIGIOUS FREEDOM}

Before turning to the historical evidence, it is important to explain two general theories of religious freedom that animate modern debates about the Free Exercise Clause. One of these theories, labeled here as the individual liberty theory, focuses on the primacy of religious duties for individuals. For adherents to this view, the core of religious liberty is individual freedom to practice religion without legal constraints, even if those legal constraints are not directly or intentionally aimed at religion. The second theory, labeled here as the neutrality theory, focuses on governmental actions. Here, the central question is whether the law treats people differently because of their religious beliefs or practices. ${ }^{29}$

The basic contours of these two theories are best illustrated through examples. Some laws would offend both theories of religious freedom. For instance, a law banning the Christian rite of communion would infringe upon the individual liberty of Christians to practice their religion, yet the same law would also be non-neutral because it would discriminate on the basis of religion. Many laws, however, would offend one approach but not the other. Forbidding all uses of wine, for example, would interfere with the individual liberty of some Christians to practice communion, but it would nonetheless be neutral because it would apply to everyone without targeting a religious practice. By contrast, a law preventing Catholics from serving in the legislature would violate neutrality principles by targeting Catholics, but it would not offend individual liberty because, strictly understood, serving in the legislature has nothing to do with Catholic religious practices. These theories are not incompatible with each other, but they nonetheless reflect fundamentally different outlooks about the source and purpose of religious liberty.

28 Recognizing that religious exemptions have constitutional underpinnings is important even if one thinks that Smith was correctly decided for prudential reasons. That is because the constitutional nature of exemption claims suggests that even if they are not judicially enforceable, other branches of government still have a constitutional duty to afford exemptions. Moreover, the prudential concerns that might have influenced the Court in Smith should be beside the point when assessing congressional attempts to protect free exercise under Section Five of the Fourteenth Amendment. But see City of Boerne v. Flores, 521 U.S. 507, 535-36 (1997).

29 Keeping largely to the terms of the founding-era debates, this Article concentrates on classifications between religious groups rather than classifications based on whether someone has any religious belief. Modern neutrality principles, of course, also prevent discrimination against those without religious faith. See, e.g., Torcaso v. Watkins, 367 U.S. 488, 495 (1961). 
As explained in the Introduction, the Supreme Court has openly adopted a neutrality-based approach to the Free Exercise Clause. In Employment Division $v$. Smith, Justice Scalia's majority opinion declared,

The free exercise of religion means, first and foremost, the right to believe and profess whatever religious doctrine one desires. Thus, the First Amendment obviously excludes all "governmental regulation of religious beliefs as such.” The government may not ... impose special disabilities on the basis of religious views or religious status . . . 30

Protecting neutrality, however, was as far as the Court was willing to go. With very limited exceptions, the Court in Smith rejected an individual liberty interpretation of religious freedom. "[T] he right of free exercise," Justice Scalia wrote, "does not relieve an individual of the obligation to comply with a "valid and neutral law of general applicability on the ground that the law proscribes (or prescribes) conduct that his religion prescribes (or proscribes)." 31 In other words, neutral laws applicable to everyone are constitutional despite any unintended burdens they might impose on religious practices. According to the Court, "Conscientious scruples have not, in the course of the long struggle for religious toleration, relieved the individual from obedience to a general law not aimed at the promotion or restriction of religious beliefs." 32 Nineteenthcentury neutrality cases, however, suggest that the Court's fleeting reference to history may have been misguided.

\section{NEUTRALITY AT THE FOUNDING}

In the 1780 s, every state constitution or declaration of rights included a religious liberty provision, although the exact language of these articles differed between states. $^{33}$ Scholars have thoroughly

30 Emp’t Div. v. Smith, 494 U.S. 872, 877 (1990) (citations omitted) (quoting Sherbert v. Verner, 374 U.S. 398, 402 (1963)).

31 Id. at 879 (quoting United States v. Lee, 455 U.S. 252, 263 n.3 (1982) (Stevens, J., concurring in the judgment)).

32 Id. (quoting Minersville Sch. Dist., Bd. of Educ. v. Gobitis, 310 U.S. 586, 594 (1940)) (internal quotation marks omitted). Gobitis was overruled on free speech grounds just three years later in West Virginia State Board of Education v. Barnette, 319 U.S. 624, 642 (1943). The Court in Barnette specifically noted that "[i]t is not necessary to inquire whether non-conformist beliefs will exempt from the duty to salute unless we first find power to make the salute a legal duty." $I d$. at 635.

33 See John WitTe, JR., \& JoEL A. Nichols, RELIGion AND the AMERICAN CONSTITUTIONAL EXPERIMENT 44, 46 (3d ed. 2011); John K. Wilson, Religion Under the State Constitutions, 1776-1800, 32 J. CHURCH \& ST. 753, 755 (1990); McConnell, Origins, supra note 18, at 1456-58 (listing each clause). In addition, although Connecticut continued under its colonial charter, the legislature passed in 1776 "An Act containing an Abstract and Declaration of the Rights and Privileges of the People of this State, and securing the same." ACTS AND LAWS OF THE STATE OF CONNECTICUT, IN AMERICA 1 (Timothy Green ed., 1784). The preamble mentions "civil and religious Rights and Liberties" and states that 
canvassed these early state constitutional provisions, but reexamining these texts is a useful starting point for understanding founding-era views about religious liberty. ${ }^{34}$

The constitution or bill of rights in most states during the Founding Era expressly mentioned that freedom of religion is an "unalienable right." 35 This reference to unalienable rights provides a critical insight

as the free Fruition of such Liberties and Privileges as Humanity, Civility and Christianity call for, as is due to every Man in his Place and Proportion, without Impeachment and Infringement, hath ever been, and will be the Tranquility and Stability of Churches and Commonwealths; and the Denial thereof, the Disturbance, if not the Ruin of both.

Id.

34 Judicial review was in its earliest stages during the 1780s. See William Michael Treanor, Judicial Review Before Marbury, 58 STAN L. REV. 455, 474 (2005); Larry D. Kramer, Marbury and the Retreat from Judicial Supremacy, 20 CONST. COMMENT. 205, 215 (2003). Therefore, state constitutional provisions may better elucidate what religious liberty meant rather than how it would be enforced. McConnell makes a similar point in an important footnote: "The exemptions of the colonial and revolutionary periods took place before the Constitution (even before the state constitutions) and before judicial review. The point of this preconstitutional history is to understand the experience against which the Framers and ratifiers would understand the proposed Amendment." McConnell, Freedom from Persecution, supra note 20, at 838 n.112. McConnell acknowledges that early state constitutional protections may have been merely legislative guidelines, but he observes that "the Framers of the federal Bill of Rights, and particularly Madison, had completed the transition from hortatory declarations to judicially enforceable rights." Id.

35 See, e.g., Del. Declaration of Rights of 1776, § 2, reprinted in 5 The Founders' Constitution 5 (Philip B. Kurland \& Ralph Lerner eds., 1987) (“[A]ll men have a natural and unalienable right to worship Almighty God according to the dictates of their own consciences and understandings . . . ."); KY. CONST. of 1792, art. XII, § 3 , reprinted in 3 The FEDERAL AND STATE CONSTITUTIONS, COlONial CHARTERS, AND OTHER Organic Laws of the States, TerRitories, AND Colonies 1264, 1274 (Francis Newton Thorpe ed., 1909) [hereinafter THE FEDERAL AND STATE CONSTITUTIONS] ("[A]ll men have a natural and indefeasible right to worship Almighty God according to the dictates of their own consciences ...."); N.H. CONST. pt. I, art. V, reprinted in 4 THE FEDERAL AND STATE Constitutions, supra, at 2453, 2454 ("Every individual has a natural and unalienable right to worship GOD according to the dictates of his own conscience, and reason . . .."); N.J. CONST. of 1776, art. XVIII, reprinted in 5 THE FEDERAL AND STATE CONSTITUTIONS, supra, at 2594, 2597 (recognizing "the inestimable privilege of worshipping Almighty God in a manner agreeable to the dictates of his own conscience"); N.C. CONST. of 1776, art. XIX, reprinted in 5 THE FEDERAL AND STATE CONSTITUTIONS, supra, at 2787, 2788 (“[A]ll men have a natural and unalienable right to worship Almighty God according to the dictates of their own consciences."); PA. CONST. of 1776, art. II, reprinted in 5 THE FEDERAL AND STATE ConstituTIONS, supra, at 3081, 3082 (“[A]ll men have a natural and unalienable right to worship Almighty God according to the dictates of their own consciences and understanding ....."). Other states spoke of religious duties. See, e.g., MD. DEClaRATION OF RIGHTS of 1776, art. XXXIII, reprinted in 3 THE FEDERAL AND STATE CONSTITUTIONS, supra, at 1686, 1689 ("[I]t is the duty of every man to worship God in such manner as he thinks most acceptable to him . ...”); MASS. ConsT. pt. 1, art. II, reprinted in 3 The Federal AND STATE Constitutions, supra, at 1888, 1889 ("It is the right as well as the duty of all men . . . to worship the SUPREME BEING . . . .); VA. CONST. of 1776, § 16, reprinted in 7 THE FEDERAL AND STATE CONSTITUTIONs, supra, at 3812, 3814 ("[R]eligion, 
into how contemporaries understood religious liberty. Under Lockean social contract theory, individuals in a state of nature have certain natural rights. These rights include both alienable rights, which individuals may give up (or alienate) upon entering the social contract, and unalienable rights. ${ }^{36}$ According to James Madison,

The Religion ... of every man must be left to the conviction and conscience of every man; and it is the right of every man to exercise it as these may dictate. This right is in its nature an unalienable right. It is unalienable, because the opinions of men, depending only on the evidence contemplated by their own minds cannot follow the dictates of other men: It is unalienable also, because what is here a right towards men, is a duty towards the Creator. ${ }^{37}$

Thus, Madison considered religious freedom to be unalienable because duties to God supersede worldly obligations. As shown in Part III, invocations of the inalienability of religious freedom were common in early constitutional debates.

Viewing religious freedom as a natural and unalienable right aligns with the individual liberty view of free exercise. Governments do not exist in the state of nature, and therefore the meaning of natural rights cannot depend upon their relationship to governmental authorities. ${ }^{38}$ Upon exiting the state of nature, however, individuals may forfeit most of their natural rights to the government, or they may redefine those rights in terms of governmental neutrality. ${ }^{39}$ But unalienable rights are different because, as Madison had explained with respect to free exercise, they cannot be given up or redefined. ${ }^{40}$ Suppose, for instance, that the right to self-defense is an unalienable right. Then suppose that the government passes a neutral law banning all intentional killings, irrespective of whether a person kills in self-defense. In this example,

or the duty which we owe to our Creator, and the manner of discharging it, can be directed only by reason and conviction ....").

36 For one description of Lockean rights theory, see DAVID A.J. RICHARDS, FOUNDATIONS OF AMERICAN CONSTITUTIONALISM 87 (1989).

37 James Madison, A Memorial and Remonstrance (June 20, 1785), in 8 THE PAPERS OF JAMES MADISON 298, 299 (Robert A. Rutland et al. eds., 1973).

38 See John Locke, SeCond Treatise of Government 8-9 (C.B. Macpherson ed., Hackett Publ'g Co. 1980) (1690); see also Richard Tuck, The Dangers of Natural Rights, 20 HARV. J.L. \& PUB. POL’Y 683, 691 (1997) ("Natural rights are obviously by definition metapolitical, though they may be adduced in discussion by legislators or interpreters of legislation ....").

39 For a useful and nuanced explanation of founding-era views on this issue, see Philip A. Hamburger, Natural Rights, Natural Law, and American Constitutions, 102 YALE L.J. 907, 935-37 (1993) [hereinafter Hamburger, Natural Rights].

40 See Madison, supra note 37, at 299 ("This duty [to God] is precedent, both in order of time and in degree of obligation, to the claims of Civil Society. . . . We maintain therefore that in matters of Religion, no man's right is abridged by the institution of Civil Society and that Religion is wholly exempt from its cognizance.”). 
prosecuting someone for an intentional killing made in self-defense would plainly violate the individual, unalienable right to self-defense. The right predates and necessarily survives the social contract, and therefore the right's definition and application do not depend on any feature of positive law, including a law's neutrality or non-neutrality. Similarly, the Founders' understanding of free exercise as an unalienable right strongly suggests that this right was individually held and not understood to be a guarantee of governmental neutrality. ${ }^{41}$

Even in the state of nature, however, individuals cannot in the name of religious liberty infringe upon the rights of others. According to John Locke, the state of nature is "a state of perfect freedom ... . yet it is not a state of licence." 42 Instead, it "has a law of nature to govern it, which obliges every one ... that being all equal and independent, no one ought to harm another in his life, health, liberty, or possessions . . . " "43

Early state constitutions mentioning the inalienability of religious freedom also recognized this fundamental limitation on religious liberty. ${ }^{44}$ In New Hampshire, for example, the constitution guaranteed the inalienability of free exercise for every person, "provided he doth not disturb the public peace, or disturb others, in their religious worship." ${ }^{5}$ Scholars dispute the meaning of these limiting provisions and particularly what it meant for someone to "disturb the peace." Hamburger asserts that the founding generation considered all violations of law to be disruptions of the public peace. ${ }^{46}$ Therefore, he argues, limiting clauses in early religious-freedom provisions expressly

41 Of course, a society that forms a social contract may also recognize a religious neutrality norm. But that does not transform neutrality into an unalienable right, which in Lockean terms is a right that predates and necessarily survives the social contract. See LOCKE, supra note 38 , at 13.

42 Id. at 8-9.

43 Id. at 9. Locke himself wrote in a time of Parliamentary sovereignty, thus making his views on the inalienability of religious rights slightly different than the views of the American founders. See McConnell, Origins, supra note 18, at 1435; see also McConnell, Freedom from Persecution, supra note 20, at 827-29 \& n.47 (presenting a slightly different reading of Locke).

44 Hamburger asserts that the inalienability of the rights of conscience proves that this right could not be conditioned, and then he uses the right's supposed unconditionality to explain why it must have been highly circumscribed. Philip Hamburger, More Is Less, 90 VA. L. REV. 835, 847-57 (2004) [hereinafter Hamburger, More Is Less]. Saying that a right is unalienable, however, is quite different than saying that it is unconditional. In the Lockean state of nature, rights did not extend so far as to allow individuals to violate the rights of others. See LOCKE, supra note 38, at 9. Indeed, Hamburger has previously articulated a similar point. See Hamburger, Natural Rights, supra note 39, at 927-28.

45 N.H. Const., pt. 1, art. V, reprinted in 4 The FEDERAL AND State CONSTITUTIONS, supra note 35, at 2453, 2454

46 Hamburger, Religious Exemption, supra note 19, at 918. 
denied an individual right of religious exemption from neutral laws. ${ }^{47}$ In making this argument, however, Hamburger makes two critical mistakes. First, he assumes the point he is trying to prove. If exemptions were statutorily or constitutionally mandated, then judges who accommodated religious scruples would be following, not violating, the law. Indeed, military-service exemptions for Quakers were widely accepted rather than condemned as "lawless" or disruptive of the public peace. ${ }^{48}$

More importantly, though, Hamburger overlooks the well-accepted eighteenth-century meaning of disruptions of the public peace. ${ }^{49} \mathrm{In}$ his famous Commentaries on the Laws of England, for instance, William Blackstone listed thirteen "offenses against the public peace" - a list that did not include every civil and criminal law on the books. ${ }^{50}$ Similarly, the Articles of Confederation stated that "the members of Congress shall be protected in their persons from arrests and imprisonments, during the time of their going to and from, and attendance on Congress, except for treason, felony, or breach of the peace." 51 Of course, this protection from "arrests and imprisonments" would have been nugatory if the phrase "breaches of the peace" included any illegal act. An early dictionary the Supreme Court has used to establish the original public meaning of other constitutional provisions ${ }^{52}$ provides that "[a] violation of the public

47 Id. at 917-26. Hamburger states, "The behavior described by the caveats included more than just nonpeaceful behavior. . . . Whereas McConnell assumes that a disturbance of the peace was simply nonpeaceful behavior, eighteenth-century lawyers made clear that "every breach of law is against the peace."' $I d$. at 918 (quoting Queen v. Lane, (1704) 87 Eng. Rep. 884 (Q.B.) 885; 6 Mod. 128, 128). Justice Scalia used this quotation in his concurring opinion in City of Boerne v. Flores, 521 U.S. 507, 539 (1997) (Scalia, J., concurring in part).

48 Hamburger's own evidence in an early episode of controversy surrounding Quaker militia exemptions in the Revolutionary War largely supports this point. See Philip Hamburger, Religious Freedom in Philadelphia, 54 EMORY L.J. 1603, 1625 (2005) [hereinafter Hamburger, Religious Freedom]. To be sure, there were adamant denials that Quakers should be exempted and not have to pay an equivalent, but the overwhelming thrust of Hamburger's evidence takes for granted the idea that militia exemptions for Quakers fall with the understood meaning of religious freedom. See, e.g., Commonwealth v. Smith, 9 Mass. (8 Tyng) 107, 110 (1812) (discussing how Quakers were usually either exempted or excused from serving as grand jurors).

49 The most thorough rebuttal of Hamburger's position regarding disturbances of the peace appears in Thomas Y. Davies, The Fictional Character of Law-and-Order Originalism: A Case Study of the Distortions and Evasions of Framing-Era Arrest Doctrine in Atwater v. Lago Vista, 37 WAKE Forest L. REV. 239, 280-300 (2002); see also McConnell, Freedom from Persecution, supra note 20, at 834-37.

504 William BLackstone, Blackstone's COMMENTARIES ON THE LAWS OF ENGLAND 113-18 (Wayne Morrison ed., 2001).

51 ARTICLES OF CONFEDERATION of 1777 , art. V (emphasis added).

52 See, e.g., Crawford v. Washington, 541 U.S. 36, 51 (2004) (relying on Noah Webster's dictionary to define the term "witnesses" in the Confrontation Clause). 
peace, as by a riot, affray, or any tumult which is contrary to law, and destructive to the public tranquility, is called a breach of the peace." ${ }_{53}$

Therefore, when state constitutions guaranteed the "unalienable rights of conscience," except when individuals disturbed the public peace, these constitutional provisions recognized the basic idea of Lockean rights: Individuals may exercise their rights so long as they do not encroach upon the rights of others.

This is not to say that neutrality was wholly unimportant. Many state constitutions also included clauses that contemplated limited forms of religious neutrality, particularly by circumscribing or renouncing state religious establishments. ${ }^{54}$ These provisions, however, were often in separate sections and generally did not affect the scope of free exercise protections. ${ }^{55}$ An interesting exception appears in the constitutions of New York and South Carolina, which declared that the "free exercise and enjoyment of religious profession and worship, without discrimination or preference, shall forever hereafter be allowed, within this State, to all mankind ...." 56 This provision may appear to be a straightforward endorsement of governmental neutrality. A closer reading, however, reveals that the modifier "without discrimination or preference" applies to the phrase "free exercise and enjoyment of religious profession and worship" and not to the enactment of laws generally. ${ }^{57}$ In other words, the right of free exercise had to be respected

53 Noah Webster, American Dictionary of the English Language (photo. reprint 2005) (1828).

54 See, e.g., PA. Const. of 1790, art. IX, § 3, reprinted in 5 The Federal AND State CONSTITUTIONS, supra note 35, at 3092, 3100 (providing that "no preference shall ever be given, by law, to any religious establishments or modes of worship"). Even Massachusetts, which had an official religious establishment, also had a constitutional guarantee that every Christian sect was under the equal protection of the law. MASS. CONST. pt. I, art. III, reprinted in 3 THE FEDERAL AND STATE CONSTITUTIONS, supra note 35, at 1888, 1890 ("And every denomination of Christians, demeaning themselves peaceably, and as good subjects of the commonwealth, shall be equally under the protection of the law: and no subordination of any one sect or denomination to another shall ever be established by law.”).

55 See, e.g., PA. CONST. of 1790, art. IX, § 4, reprinted in 5 The FEDERAL AND STATE Constitutions, supra note 35, at 3092, 3100 ("[N]o person, who acknowledges the being of a God and a future state of rewards and punishments, shall, on account of his religious sentiments, be disqualified to hold any office or place of trust or profit under this commonwealth"); id. $\S 3$ ("[N]o preference shall ever be given, by law, to any religious establishments or modes of worship.").

56 N.Y. Const. of 1777, art. XXXVIII, reprinted in 5 The Federal AND STATe CONSTITUTIONS, supra note 35, at 2623, 2637 (emphasis added); S.C. Const. of 1790, art. VIII, $\S 1$, reprinted in 6 THE FEDERAL AND STATE CONSTITUTIONS, supra note 35, at 3258, 3264 (emphasis added).

57 If one took a strict view of neutrality, it would be difficult to see how religious exemptions themselves would not constitute a "discrimination or preference." Yet "there is virtually no evidence that anyone thought [regulatory religious exemptions] were 
equally, but this did not prevent the government from treating certain religious groups differently than others in ways that did not infringe upon that right. ${ }^{58}$

Given the modern primacy of governmental neutrality with respect to religious beliefs, it is easy to view the individual liberty approach to free exercise as expansive or even radical. According to Hamburger, "most eighteenth-century advocates of religious liberty sought a freedom from laws that imposed constraints on the basis of religion (or at least religious differences), [but] numerous modern advocates and judges expect more. . . . They thereby adopt a very expansive definition of the First Amendment's right of free exercise."59 Applied to our modern circumstances, the scope of the individual liberty approach may, in fact, be expansive. The Supreme Court currently considers the neutrality theory as a baseline, ${ }^{60}$ so mandatory exemptions would increase the scope of free exercise, based on the current doctrine.

In the eighteenth century, however, religious exemptions were highly non-radical. As William Marshall has mentioned, "[T]here [were] few religiously neutral state provisions with which the religious practices could have been in conflict. The regulatory state did not exist." 61 Moreover, "[T]he culture of the United States in the late eighteenth century was fairly homogeneous, being composed almost entirely of Christian sects whose practices were unlikely to violate non-

constitutionally prohibited or that they were part of an establishment of religion." Douglas Laycock, Regulatory Exemptions of Religious Behavior and the Original Understanding of the Establishment Clause, 81 NoTRE DAME L. REV. 1793, 1796 (2006).

58 Thus, when the New York Constitutional Ratification Convention proposed in 1788 that "the People have an equal, natural and unalienable right, freely and peaceably to Exercise their Religion according to the dictates of Conscience, and that no Religious Sect or Society ought to be favoured or established by Law in preference of others," the equal right to free exercise meant that the right existed regardless of a person's religion, not that all religions had to be treated equally under the law. Ratification of the Constitution by the State of New York (July 26, 1788), in 2 DocumentaRY History OF THE Constitution of the United StAtes of America 191 (Dep't of State ed., 1894). Similar language appeared in Virginia's 1776 Bill of Rights, which proclaimed that "religion, or the duty which we owe to our Creator, and the manner of discharging it, can be directed only by reason and conviction, not by force or violence; and therefore all men are equally entitled to the free exercise of religion, according to the dictates of conscience . . . . VA. ConsT. of 1776, § 16, reprinted in 7 The FEDERAL AND STATE CONSTITUTIONS, supra note 35, at 3812, 3814 (emphasis added).

59 Hamburger, More Is Less, supra note 44, at 836 (emphasis added). Hamburger, however, argues that state free exercise clauses were generally even more limited, applying only to state-imposed prohibitions on religious practices rather than any religious classification. $I d$. at 841.

60 See supra note 30 and accompanying text.

61 William P. Marshall, The Case Against the Constitutionally Compelled Free Exercise Exemption, 7 J.L. \& RELIGION 363, 382 (1989). 
religious societal norms." 62 In some notable instances, neutral laws did conflict with individual liberty. Quakers, for example, had conscientious scruples against swearing oaths and serving in the military. ${ }^{63}$ Faced with this dilemma, however, states readily granted religious accommodations throughout the first decades of the young republic, apparently with little social cost. ${ }^{64}$ In addition to the rarity of conflicts between individual religious scruples and neutral laws, several important backstops prevented conscientious-objection claims from destabilizing the legal regime. Prevailing religious norms still placed a high premium on conformity to church doctrine, and the government generally recognized only those conscientious objections shared by an entire denomination..$^{65}$ Therefore, guaranteeing religious exemptions as a constitutional principle did not mean a free-for-all in practice, where any individual could claim and receive exemptions on a whim. ${ }^{66}$ Additionally, as it had in the state of nature, religious liberty did not permit individuals to interfere with the rights of others, thus giving states yet another means of limiting exemptions. ${ }^{67}$

De facto limits on religious exemptions help explain why the Federal Free Exercise Clause received such little debate. Recently, Nicholas Rosenkranz argued that the First Amendment's famous opening phrase, "Congress shall make no law," implies that the Free Exercise Clause prevents facially discriminatory laws but does not provide an individual right to conscientious exemption. ${ }^{68}$ In his initial remarks on the clause, however, James Madison suggested a different reason why the First Amendment only mentions Congress:

Whether the words [of the amendment] are necessary or not, he did not mean to say, but they had been required by some of the State Conventions, who seemed to entertain an opinion that under the clause of the constitution, which gave power to Congress to make all laws necessary and proper to carry into execution the Constitution, and the laws made under it, enabled them to make laws of such a

$62 \quad I d$. at 383.

63 See, e.g., Commonwealth v. Smith, 9 Mass. (8 Tyng) 107, 110 (1812); see also Hamburger, Religious Freedom, supra note 48, at 1625.

64 See McConnell, Origins, supra note 18, at 1466-73 (discussing common eighteenth-century exemptions); see also infra note 89.

65 McConnell, Origins, supra note 18, at 1472.

66 See Campbell, supra note 20, at 978-79.

67 See McConnell, Freedom from Persecution, supra note 20, at 845-46.

68 Nicholas Quinn Rosenkranz, The Subjects of the Constitution, 62 STAN. L. REV. 1209, 1263, 1266-68 (2010). Other textually-based critiques of the individual-liberty view focus on the word "prohibiting." See, e.g., Allan Ides, The Text of the Free Exercise Clause as a Measure of Employment Division v. Smith and the Religious Freedom Restoration Act, 51 WASH. \& LEE L. REV. 135, 147-51 (1994). But see McConnell, Origins, supra note 18, at 1486-88 (responding to the argument that the word "prohibiting" mediates against the individual liberty view of free exercise). 
nature as might infringe the rights of conscience, and establish a national religion; to prevent these effects he presumed the amendment was intended, and he thought it as well expressed as the nature of the language would admit. ${ }^{69}$

If Madison's views are representative, specifying that Congress shall not prohibit the free exercise of religion was an antidote to lingering concern about the Necessary and Proper Clause. It was not a subtle repudiation of the inalienability of religious freedom.

Indeed, evidence from the drafting of the First Amendment belies the idea that the First Congress recognized something other than the prevailing concept of religious freedom. On August 15, 1789, for instance, some delegates expressed concern over whether the text of the current draft_-"no religion shall be established by law, nor shall the equal rights of conscience be infringed"-could be misconstrued to prohibit state establishments or even church bylaws. ${ }^{70}$ Responding to this objection, Samuel Livermore proposed an alternative: "Congress shall make no laws touching religion, or infringing the rights of conscience." 71 Daniel Carroll remarked that he "would not contend with gentlemen about the phraseology," but rather wanted "to secure the substance in such a manner as to satisfy the wishes of the honest part of the community." 72 Indeed, the delegates were not debating the meaning of free exercise at all. Rather, they were trying to ensure that the text of the Establishment Clause would not be construed to interfere with state laws or church bylaws. Modern legal scholars who use hyper-technical textual readings to interpret the Free Exercise Clause are simply missing the point. The use of words like "Congress" or "prohibiting" in the Free Exercise Clause had nothing to do with how contemporaries would have understood the substance of the right itself.

Yet Madison's musings about whether the Free Exercise Clause was even necessary are also quite revealing. Indeed, in the eighteenthcentury context, it was hard to imagine how Congress could possibly have interfered with an individual's free exercise of religion. Other provisions of the Constitution precluded federal interference with religious liberty by allowing affirmations instead of oaths and by granting states, rather than Congress, control over militia attendance laws. ${ }^{73}$ Other than these well-known areas, there were scarcely other

69 1 Annals of Cong. 730 (1789) (Joseph Gales ed., 1834).

70 Id.

$71 \quad$ Id. at 731.

72 Id. at 730 .

73 U.S. CONST. art. VI (“[A]ll executive and judicial Officers, both of the United States and of the several States, shall be bound by Oath or Affirmation, to support this Constitution; but no religious Test shall ever be required as a Qualification to any Office or public Trust under the United States.”); U.S. ConST. art. I, § 8, cl. 16 (“[R]eserving to the 
ways federal laws could have burdened free exercise. ${ }^{74}$

Many founding-era laws, however, drew distinctions on the basis of religion, thus defying incipient notions of religious neutrality. For instance, most states used religious distinctions to prevent some individuals from serving as legislators or as courtroom witnesses. ${ }^{75}$ Blasphemy prosecutions and religious assessment laws also conflicted with religious neutrality. ${ }^{76}$ Although largely overlooked, the controversies surrounding these laws demonstrate that in eighteenthcentury and early nineteenth-century terms, contrary to our modern understanding, religious neutrality was the far more radical and expansive theory of religious freedom.

\section{EARLY DEBATES OVER NEUTRALITY}

Almost all historical examinations of religious freedom concentrate on early exemption decisions without also considering neutrality cases. ${ }^{77}$ Despite this modern scholarly imbalance, nineteenth-century neutrality cases were far more prevalent than exemption cases. The most common controversies involved the constitutionality of testimonial exclusions, test oaths, blasphemy laws, and religious assessments. Participants in early debates about religious neutrality repeatedly referred to the individual liberty theory as the core, and often the extent, of constitutionally protected religious liberty. Gradually, however, Americans in the first half of the nineteenth century embraced a more inclusive vision of religious freedom that included wider protections of governmental neutrality.

\section{A. Testimonial Exclusions}

In the late eighteenth century, oaths were explicitly religious. Swearing on the Bible or another religious book constituted an

States respectively, the Appointment of the Officers, and the Authority of training the Militia...."). Before the First Amendment was ratified, the House of Representatives passed a bill granting Quakers exemptions from militia service, though the Senate apparently rejected this language. See Vincent Phillip Muñoz, The Original Meaning of the Free Exercise Clause: The Evidence from the First Congress, 31 HARV. J.L. \& PUB. POL'Y 1083, 1085-86 (2008) (arguing that the First Congress did not agree to exemptions). Federal law, however, did not reject exemptions. See id. at 1120. It merely left the issue to be decided by state governments.

74 Another area of nineteenth-century litigation concerned whether Jews were exempt from serving as jurors or witnesses on Saturday. See, e.g., Philips v. Gratz, 2 Pen. \& W. 412, 412 (Pa. 1831); Stansbury v. Marks, 2 Dall. 213, 213 (Pa. 1793). I have not discovered any such conflicts in federal court.

75 See infra Parts III.A-B.

76 See infra Parts III.C-D.

77 See, e.g., McConnell, Origins, supra note 18, at 1503. But see Bradley, supra note 19 , at 272-77 (discussing testimonial exclusion and blasphemy cases, though arguing that these cases did not involve laws targeting religion). 
invocation of divine punishment against perjury. ${ }^{78}$ Originally at common law, only Christians were allowed to swear under oath. ${ }^{79}$ During the seventeenth and eighteenth centuries, however, English courts slowly allowed exceptions to the strict common-law rule, primarily to allow testimony from Jewish merchants. ${ }^{80}$ The result of this transition was the general rule announced by Lord Chief Justice John Willes in Omychund $v$. Barker that swearing an oath required belief in God and belief in hell. ${ }^{81}$ According to Lord Chief Justice Willes, any persons "who believe [in] God, and future rewards and punishments in the other world, may be witnesses; yet I am as clearly of opinion, that if they do not believe [in] God, or future rewards and punishments, they ought not to be admitted as witnesses." 82 While the rule allowed most non-Christians to swear oaths, it still required certain religious beliefs. As George Washington asked rhetorically in his 1796 Farewell Address, "[W]here is the security for property, for reputation, for life, if the sense of religious obligation desert the oaths, which are the instruments of investigation in Courts of Justice?" 83

Quakers as well as certain other Christians believed in God and future rewards and punishments, which normally would have been sufficient to allow them to testify, but they famously refused to swear oaths because of their literal interpretation of the biblical injunction: "Swear not at all . . . " ${ }^{84}$ This refusal to swear oaths because of conscientious scruples brought the common-law rule into conflict with religious beliefs and not only left those Christians unable to serve as witnesses or jurors but also left them susceptible to contempt charges for refusing to fulfill their legal obligations in response to subpoenas and jury summonses. ${ }^{85}$ This had the potential to place effective criminal sanctions on certain religious beliefs. ${ }^{86}$ In response, colonial and state

78 See Curtiss v. Strong, 4 Day 51, 55-56 (Conn. 1809).

79 See B.H. Hartogensis, Denial of Equal Rights to Religious Minorities and NonBelievers in the United States, 39 YALE L.J. 659, 661 \& n.12 (1930).

80 Omychund v. Barker, (1744) 26 Eng. Rep. 15 (Ch.) 30; 1 Atk. 21, 44 (Lord Willes, C.J.).

81 Id. at $31 ; 1$ Atk. at 45 .

82 Id. In a later report of the Omychund decision, supposedly based on Willes's original manuscripts, Willes was reported to have said that a person may be admitted if he "believes a God and that he will reward and punish him in this world, but does not believe a future state ...." Omichund v. Barker, (1744) Willes 538 (Ch.) 550 (Lord Willes C.J.).

8335 The Writings of George Washington 229 (John C. Fitzpatrick ed., 1940).

84 Matthew 5:34 (King James).

85 E.g., Bryan's Case, 1 D.C. (1 Cranch) 151, 151 (C.C. 1804) (holding a juror, who was a member of the Methodist denomination, in contempt for refusing to swear); M'Intire's Case, 1 D.C. (1 Cranch) 157, 157 (C.C. 1803) (holding a juror in contempt for refusing to swear).

86 See Bryan's Case, 1 D.C. (1 Cranch) at 151. 
governments passed laws allowing affirmations instead of oaths from Quakers and members of other sects known to have religious scruples. ${ }^{87}$ According to Connecticut Supreme Court Justice Zephaniah Swift,

There is no appeal to God in an affirmation. It is merely a declaration that the affirmant will speak the truth, upon the pains and penalties of perjury: yet, there is no question but that Quakers pay as much regard to the truth under an affirmation, as other denominations of christians under an oath, and are entitled to as much credit. 88

And in those states that did not authorize affirmations in lieu of oaths, Quakers and other religious objectors received routine exemptions from serving as jurors or witnesses. ${ }^{89}$ The near universality of these exemptions shows that state laws were, at a minimum, consistent with an individual liberty theory of religious freedom.

Oaths themselves, however, remained explicitly religious and were therefore incongruous with a neutrality-based understanding of religious freedom. In one of the first reported challenges to the common-law incompetency rule, the Connecticut Supreme Court of Errors reaffirmed the necessity of religious qualifications:

Every person who does not believe in the obligation of an oath, and a future state of rewards and punishments, or any accountability after death for his conduct, is by law excluded from being a witness; for to such a person the law presumes no credit is to be given. Testimony is not to be received from any person in a court of justice, but under the sanction of an oath. It would therefore be idle to administer an oath to a man who disregards its obligation. . . . [T] he fear of offending God should have its influence upon a witness to induce him to speak the truth. But no such influence can be expected from the man who disregards an oath. ${ }^{90}$

87 See McConnell, Origins, supra note 18, at 1467-68.

88 Zephaniah Swift, A Digest of the LaW of Evidence, in Civil and Criminal CASES 51 (photo. reprint 1972) (1810).

89 See, e.g., Commonwealth v. Smith, 9 Mass. (8 Tyng) 107, 110 (1812) ("Before the recent statute ... Quakers, and persons scrupulous of taking judicial oaths, were either exempted or excused from serving on the grand jury ....”); see also Philips v. Gratz, 2 Pen. \& W. 412, 416 (Pa. 1831) ("The religious scruples of persons concerned with the administration of justice will receive all the indulgence that is compatible with the business of government; and had circumstances permitted it, this cause would not have been ordered for trial on the Jewish Sabbath."); Guardians of the Poor v. Greene, 5 Binn. 554, 562 (Pa. 1813) ("[P]ublic ministers of all denominations returned as jurors, have uniformly been excused by the Court on their application."); State v. Willson, 13 S.C.L. (2 McCord) 393, 396 (1823) (mentioning "certain instances of individuals being excused" from jury duty because of conscientious scruples).

90 Curtiss v. Strong, 4 Day 51, 55-56 (Conn. 1809); see also State v. Cooper, 2 Tenn. (2 Overt.) 96, 96 (1807) (Campbell, J.) (finding that "no man who did not believe in a future state of existence, rewards and punishments, could be a witness"); Important Judicial Decision, 1 AM. MonTHLy MAG. \& CRITICAL REV. 64, 65 (1817) (reporting that Chief Justice 
Witness competency rules were not meant as a form of punishment for those who disbelieved in God or future punishment. Nevertheless, the common-law incompetency rule explicitly discriminated between individuals on the basis of religious belief. ${ }^{91}$

In Jackson, ex dem. Tuttle v. Gridley, the highest appellate court in New York heard a novel challenge to the common-law oath requirements. ${ }^{92}$ A trial judge advised the jury to disregard an avowed atheist's testimony because the atheist purportedly lacked the beliefs necessary to feel bound by an oath. ${ }^{93}$ On appeal, the party offering the witness's testimony argued that the State's constitutional guarantee of religious freedom had abrogated common-law exclusions based on religious belief. ${ }^{94}$ Chief Justice Ambrose Spencer replied,

Religion is a subject on which every man has a right to think according to the dictates of his understanding. It is a solemn concern between his conscience and his God, with which no human tribunal has a right to meddle. But in the development of facts, and the ascertainment of truth, human tribunals have a right to interfere. They are bound to see that no man's rights are impaired or taken away, but through the medium of testimony entitled to belief; and no testimony is entitled to credit, unless delivered under the solemnity of an oath, which comes home to the conscience of the witness, and will create a tie arising from his belief that false swearing would expose him to punishment in the life to come. On this great principle rest all our institutions, and especially the distribution of justice between man and man. ${ }^{95}$

At first glance, Spencer seems to have articulated a compelling governmental interest for discriminating on the basis of religious belief. Indeed, protection of other rights was a well-accepted justification for allowing infringements upon religious liberty. ${ }^{96}$ On a closer reading, though, Spencer seems mostly concerned with the act of investigating a witness's religious views, not with any subsequent discrimination on the basis of those views. ${ }^{97}$ According to Spencer, religious beliefs are a

John Louis Taylor of North Carolina had recently excluded a witness who professed disbelief in "either a heaven or a hell").

91 Accord Bradley, supra note 19, at 274-75.

92 Jackson, ex dem. Tuttle v. Gridley, 18 Johns. 98, 106 (N.Y. Sup. Ct. 1820).

93 Amos Gridley, the contested witness, had allegedly denied belief in God, though he stated shortly before the trial that "he had formerly embraced the principles of the Universalists, and rather believed it was right." Id. at 99.

94 Id. at 101, 103.

$95 \quad I d$. at 106.

96 See supra notes $42-45$ and accompanying text; McConnell, Freedom from Persecution, supra note 20, at 845-46.

97 Gridley, 18 Johns. at 104 ("[T] $]$ he most religious witness may be scandalized by the imputation which the very question implies."). 
"solemn concern between [a man's] conscience and his God."98 Yet government had a right to "meddle" or "interfere" with religious privacy when there was sufficient doubt about a person's religious fitness to testify in court. ${ }^{99}$ In other words, Spencer's focus was on the rights of the individual, not a fear of governmental discrimination. Indeed, when a prospective witness's religious qualifications were in doubt, the prevailing method of ascertaining those beliefs was hearsay evidence rather than direct questioning because the latter was thought to interfere with a person's freedom of conscience. ${ }^{100}$ As Judge Swift wrote in his widely distributed evidence treatise, "A man's opinions are matters between himself and his God, so long as he does not disclose them, and it is wholly inconsistent with the rights of conscience, to compel him to do it." 101

Although some courts allowed testimony from witnesses who did not believe in future punishment, ${ }^{102}$ courts generally rejected arguments based on religious liberty. In Atwood v. Welton, for example, the Connecticut Supreme Court reexamined its holding from Curtiss $v$. Strong, ${ }^{103}$ which affirmed the common-law incompetency rule. ${ }^{104}$ This time, however, an attorney raised a constitutional objection to the process of excluding witnesses based on their religious beliefs. ${ }^{105}$ The court acknowledged that "a man ought not to be [directly] questioned respecting his religious opinions," but it upheld the constitutionality of testimonial exclusions when hearsay evidence proved that a prospective witness did not believe in God or future rewards and punishments. ${ }^{106}$ The court declared,

The plain meaning of these [constitutional] provisions, is to secure an entire freedom in religious profession and worship and an entire exclusion by law of any preference to any sect or mode of worship. No man shall be prohibited from professing what religion he pleases, or

\footnotetext{
$98 \quad I d$. at 106.

99 Id.

100 See SwIFT, supra note 88, at 18.

101 Id.
}

102 These courts usually did not articulate reasons why such witnesses should be admitted contrary to the common-law rule. See, e.g., Hunscom v. Hunscom, 15 Mass. (14 Tyng) 184, 184 (1818) (allowing a witness who "professed disbelief of a future state of existence" to be sworn in); cf. Noble v. People, 1 Ill. (Breese) 54, 55-56 (1822) (admitting witness who did not believe in future punishments but believed in God and a future state). Some courts based their decisions on different understandings of the common law rather than constitutional arguments about religious liberty. See, e.g., People v. Matteson, 2 Cow. 433, 434-35 (N.Y. Oyer \& Terminer 1824).

103 Curtiss v. Strong, 4 Day 51, 55-56 (Conn. 1809).

104 Atwood v. Welton, 7 Day 66, 82 (Conn. 1828).

$105 I d$. at $68,77$.

106 Id. at $73-74$. 
worshipping in any manner he pleases; nor shall there be any religious establishment, or approximation towards it, by any law giving any preference to any sect or mode of worship. ${ }^{107}$

"But," the court asked rhetorically, "cannot a person be free in his profession and worship, who is excluded from giving testimony, on the ground of his denial of all liability to future punishment? How does his exclusion affect his belief, profession or mode of worship? It has no possible bearing on either."108 In other words, religious freedom is infringed upon only if a law "affects" a person's "belief, profession, or mode of worship," not when a law discriminates between individuals on the basis of their religious beliefs.

Excluding witnesses because of disqualifying religious beliefs was widespread and well-accepted at the founding, but by the late $1820 \mathrm{~s}$, it was becoming increasingly disfavored. In 1827, a chancery decision in South Carolina articulated the emerging neutrality-based argument for overturning the common-law rule. ${ }^{109}$ The case involved the competency of a witness who denied the possibility of divine punishment after death. ${ }^{110}$ Counsel in support of the witness argued that excluding him would contravene South Carolina's free exercise clause. ${ }^{111}$ Opposing counsel responded, "[T]he inquiry into [the witness's] religious opinions did not contravene . . . the Constitution [because] he might still enjoy his religious profession, and worship notwithstanding such exclusion, and... the exclusion would merely operate on his civil and not his religious rights." 112

In deciding the case, Chancellor Henry William DeSaussure interpreted the common law as allowing the witness to testify. ${ }^{113}$ In addition, DeSaussure expounded upon his understanding that the state constitution prohibited the government from placing religious restrictions on an individual's enjoyment of civil rights:

If a man's religious opinions are made a ground to exclude him from the enjoyment of civil rights, then he does not enjoy the freedom of his religious profession and worship. His exclusion from being a witness in Courts of Justice is a serious injury to him; it is also degrading to him and others who think with him. If men may be excluded for their religious opinions, from being witnesses, they may be excluded from being Jurors or Judges; and the Legislature might enact a law excluding such persons from holding any other office, or serving in the Legislature, or becoming teachers of schools, or professors of colleges.

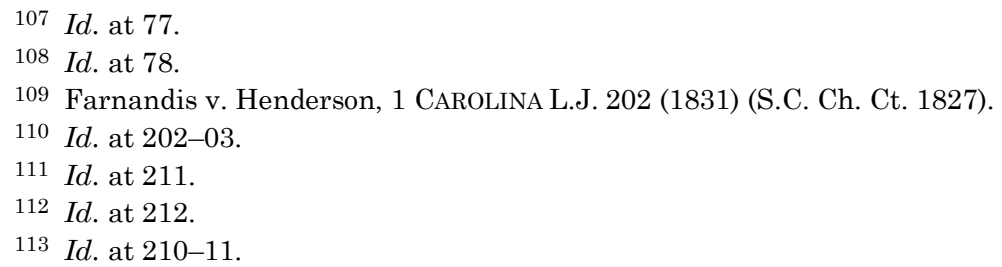


In my judgment this would be in the very teeth of the Constitution, and would violate the spirit of all our institutions. . . . It would seem to me to be a mockery to say to men, you may enjoy the freedom of your religious professions and worship; but if you differ from us in certain dogmas and points of belief, you shall be disqualified and deprived of the rights of a citizen, to which you would be entitled but for those differences of religious opinion. ${ }^{114}$

DeSaussure's eloquent decision was at the vanguard of a neutralitybased view of religious liberty and expresses a view similar to modern unconstitutional-conditions doctrine. ${ }^{115} \mathrm{His}$ opinion illustrates a growing yet still contested notion that the government should not discriminate on the basis of religious belief. ${ }^{116}$ Religious freedom, however, remained first and foremost an individual liberty concern. ${ }^{117}$ The concept of religious liberty was gradually expanding beyond-but not yet displacing-its individual liberty core.

\section{B. Religious Tests}

In addition to imposing religious requirements for testifying in court, several states also placed religious tests for officeholders into their constitutions. ${ }^{118}$ Debates over these provisions often paralleled the

114 Id. at 212.

115 The connection between a constitutional requirement of neutrality and the unconstitutional-conditions doctrine is well-recognized in existing scholarship. See, e.g., Kathleen M. Sullivan, Unconstitutional Conditions, 102 HARV. L. REV. 1413, 1490 (1989) ("[A]n unconstitutional condition can skew the distribution of constitutional rights among rightholders because it necessarily discriminates facially between those who do and those who do not comply with the condition. If government has an obligation of evenhandedness or neutrality with regard to a right, this sort of redistribution is inappropriate."); Cass R. Sunstein, Why the Unconstitutional Conditions Doctrine Is an Anachronism (with Particular Reference to Religion, Speech, and Abortion), 70 B.U. L. REV. 593, 616 (1990) ("If the relevant constitutional provision requires neutrality, consideration of conscientious objections is probably illegitimate and, in any case, insufficiently weighty to justify selective decisionmaking. A decision to fund Christian but not Jewish art, or paintings favorable to Republicans, would be plainly unconstitutional.”).

116 The next reported decision that cited constitutional grounds for overturning common-law exclusions came almost twenty years later in Perry v. Commonwealth, $44 \mathrm{Va}$. (3 Gratt.) 645, 654-55 (1846) (stating that Virginia's Bill of Rights abrogated the commonlaw exclusion rule). Judges could also use other arguments to allow religious groups like Universalists to testify, and many legislatures took steps to ensure that courts did not discriminate on religious grounds. See Ronald P. Formisano \& Stephen Pickering, The Christian Nation Debate and Witness Competency, 29 J. EARLY REPUBLIC 219, 227, 232-33 (2009); Thomas Raeburn White, Oaths in Judicial Proceedings and Their Effect upon the Competency of Witnesses, 51 AM. L. REG. 373, 392-93 \& n.39 (1903).

117 See McConnell, Origins, supra note 18, at 1446.

118 The five states with test oath provisions in their constitutions in 1789 were Delaware, Maryland, Massachusetts, North Carolina, and Pennsylvania. DEL. Const. OF 1776, art. XXII, reprinted in 1 THE FEDERAL AND STATE CONSTITUTIONS, supra note 35, at 562, 566; MD. Const. of 1776, art. LV, reprinted in 3 The FEDERAL AND STATE CONSTITUTIONS, supra note 35, at 1686, 1700; MASS. CONST. pt. 2, ch. VI, art. I, reprinted 
arguments made in the context of witness exclusions. Contemporaries occasionally understood these provisions as infringements on the rights of conscience. ${ }^{119}$ Generally, however, public comments reflected an emphasis on individual liberty rather than governmental neutrality.

In arguing that test oaths violated the rights of conscience, some people framed their critiques in terms of individual liberty. Jewish leader Jonas Phillips, for example, pleaded in a petition to the 1787 Philadelphia Convention that "to swear and believe [in certain Christian tenets] is absolutly [sic] against the religious principle of a Jew[] and [it] is against his Conscience to take any such oath." 120 Constitutional Framer and future Supreme Court Chief Justice Oliver Ellsworth articulated his opposition to test oaths in slightly different terms:

[T] he sole purpose and effect of [the Federal Constitution's No Religious Test Oath Clause] is to exclude persecution, and to secure to [the people] the important right of religious liberty. We are almost the only people in the world, who have a full enjoyment of this important right of human nature. In our country every man has a right to worship God in that way which is most agreeable to his own conscience. If he be a good and peaceable citizen, he is liable to no penalties or incapacities on account of his religious sentiments; or in other words, he is not subject to persecution.

....

... A test-law is the parent of hypocrisy, and the offspring of error and the spirit of persecution. Legislatures have no right to set up an inquisition, and examine into the private opinions of men. ${ }^{121}$

In this passage, Ellsworth advocates for governmental neutrality, but he frames this argument in terms of individual liberty, not in terms of a right to equal treatment. According to Ellsworth, excluding people from the legislature was a type of "penalty or incapacity," thus punishing particular religious convictions. ${ }^{122}$ Moreover, like Judge Spencer later recognized in Jackson, ex dem. Tuttle v. Gridley, Ellsworth thought test

in 3 The Federal and STATe Constitutions, supra note 35, at 1888, 1908; N.C. Const. of 1776, art. XXXII, reprinted in 5 THE FEDERAL AND STATE CONSTITUTIONS, supra note 35, at 2787, 2793; PA. Const. of $1776, \S 10$, reprinted in 5 The FEDERAL AND STATE Constitutions, supra note 35, at 3081, 3085. The Federal Constitution bans federal test oaths. U.S. CONST. art. VI ("[N]o religious Test shall ever be required as a Qualification to any Office or public Trust under the United States.").

119 See, e.g., Letter from Jonas Phillips to President and Members of the Convention (Sept. 7, 1787), in 4 The Founders' Constitution 638 (Philip B. Kurland \& Ralph Lerner eds., 2000).

$120 \mathrm{Id}$.

121 Oliver Ellsworth, “A Landholder” VII, CONN. CouRANT, Dec. 17, 1787, reprinted in The Debate on the Constitution: Federalist and Antifederalist Speeches, ARTiCLES, AND LetTers DURING THE STRUGGLe OVER RATIFiCATION 521, 522, 525 (Bernard Bailyn ed., 1993).

122 See id. at $522-23$. 
oaths constituted a governmental inquisition into religious beliefs and therefore interfered with the individual right of conscience. ${ }^{123}$

Discussions at the 1820 Massachusetts Constitutional Convention illustrate the arguments made in support of religious tests. At that time, Massachusetts still had various non-neutral laws. The state collected special religious taxes to support local pastors, ${ }^{124}$ and it required many state officeholders to swear the following: "I believe the Christian religion, and have a firm persuasion of its truth . ..."125 As the delegates congregated in 1820, some wanted the convention to reconsider the religious test oath required of all public officials. ${ }^{126}$ In pursuit of this goal, reformers such as James Prince often invoked religious freedom. In one of the most detailed attacks on religious tests, Prince explained,

There are ... two distinct rights belonging to man-UNALIENABLE and NATURAL - among those of the first class are the rights of conscience in all matters of religion. ... [A]s man owes supreme allegiance to God, as the Creator, and as the undivided governor of the universe, he cannot absolve himself, nor can others absolve him from this supreme allegiance; and hence, on entering into a social compact, the rights he gives up, and the powers he delegates must be tributary to, and in subordination to this high and first allegiance .... ${ }^{127}$

Because religious duties are supreme, and because governmental authority is subordinate to those duties, Prince then concluded that "on entering into the social compact, every man has a right to enter on equal terms; but, if the consciences of men are in any wise shackled by forms or qualifications, this would not be the case."128 Therefore, according to Prince, inequality in the treatment of different religions violates the basic terms of the social contract. Notably, Prince was not opposing an individual liberty view of religious freedom. Instead, much like Ellsworth, he explicitly used an individual liberty framework to justify governmental neutrality. According to Prince, the government could not

123 Jackson, ex dem. Tuttle v. Gridley, 18 Johns. 98, 106 (N.Y. Sup. Ct. 1820); Ellsworth, supra note 121, at 525; cf. Note, An Originalist Analysis of the No Religious Test Clause, 120 HARV. L. REV. 1649, 1658 (2007) (arguing that the No Religious Test Oath Clause prohibits only test oaths not religious qualifications for office). While plausible (and supportive of the thesis of this Article), this latter argument probably takes the text of the Clause too literally.

124 See infra Part III.D.

125 MASs. CONST. pt. 2, ch. VI, art. I, repealed by MASs. CONST. amend. art. VII, reprinted in 3 The FEDERAL AND STATE CONSTITUTIONS, supra note 35, at 1888, 1908.

126 Boston Daily Advertiser, Journal of Debates and Proceedings in the Convention of Delegates Chosen to Revise the Constitution of Massachusetts 83 (1821).

127 Id. at 84 .

$128 I d$. at 85 (internal quotation marks omitted). 
place conditions on the exercise of political privileges because doing so would "shackle" or punish minority religious beliefs. ${ }^{129}$

Delegates in the Massachusetts convention universally agreed that religious freedom was an unalienable right, yet most speakers rejected Prince's conclusion about test oaths. In a lengthy floor speech, future Senator Daniel Webster stated that "[n]othing is more unfounded than the notion that any man has a right to an office. . . . This qualification has nothing to do with any man's conscience. If he dislikes the condition, he may decline the office ...."130 Many delegates opposed religious tests for policy reasons but denied that test oaths interfered with freedom of conscience. ${ }^{131}$ Massachusetts Supreme Judicial Court Justice Samuel S. Wilde, for instance, argued against the propriety of religious tests but noted that they " $\mathrm{d}[\mathrm{o}]$ not interfere with the rights of conscience.-No person has any conscience about becoming a Legislator. He is not obliged to accept of office, and he has no right to claim it." ${ }^{132}$

Webster and Wilde made two points in these speeches. First, an opportunity to become a public official was not a right of citizenship, and therefore, test oaths did not infringe upon political or civil rights. Second, Webster and Wilde explained that no individual has a religious duty to serve in public office. Thus, because the law did not interfere with anyone's religious duties, it also did not interfere with the right of conscience. The obvious assumption in Webster's and Wilde's remarks is that a law can infringe upon religious freedom only if it interferes with an individual's worship or conscience.

In the end, the delegates decided by a vote of 242 to 176 to omit religious tests for office. ${ }^{133}$ While this vote reflects a trend toward separating governmental and religious concerns, the preceding debates illustrate the priorities implicit in the delegates' understandings of religious freedom. The prevailing view seems to have been that religious

129 See id. at 85-86.

130 Id. at 83-84; see also id. at 88 (remarks of Samuel Hubbard) ("The right to be elected to office was not an unalienable right. It affected neither a man's life, liberty nor conscience.").

131 See, e.g., id. at 91 (remarks of Thomas Baldwin) (arguing that tests did not violate religious freedom but were nonetheless dubious on policy grounds); $i d$. at 93 (remarks of Lovell Walker) ("Admitting that we have the right to demand [religious tests] — he doubted the expediency of it."). Samuel A. Welles agreed that a religious test oath was unwise as a policy matter, but he observed that the religious neutrality proponents were not being internally consistent:

$[\mathrm{F}]$ or if it be an interference in the right of conscience, to require that persons who may be chosen by the people to certain offices, shall swear to their belief in the christian religion, it must also be an interference in the right of conscience, Id. at 89 .

to require that they shall swear by the name of God himself . . . .

132 Id. at 90.

$133 \mathrm{Id}$. at 94. 
tests did not infringe upon the individual right of conscience; therefore, such tests should be considered in terms of their practicality, not whether they interfered with unalienable rights. The delegates were not debating exemptions, ${ }^{134}$ but their arguments seem to endorse the individual liberty theory of religious freedom.

\section{Blasphemy Prosecutions}

Blasphemy-or "open and malicious . . . reviling of God or Scripture"-was punishable at common law as a breach of the peace. ${ }^{135}$ As one judge wrote in 1838, the crime of blasphemy was "not intended to prevent or restrain the formation of any opinions or the profession of any religious sentiments whatever, but to restrain and punish acts which have a tendency to disturb the public peace." 136 Defendants in several nineteenth-century blasphemy cases, however, argued that constitutionally guaranteed religious liberty protected their religious expressions-even when blasphemous. ${ }^{137}$ The constitutional arguments in these cases were slightly different than those involved in oath cases. First, unlike an exclusion from legislative service, those convicted of blasphemy suffered criminal punishment. Moreover, test oaths and testimonial exclusions focused on an individual's underlying beliefs, whereas blasphemy prosecutions were based on an overt act. Nonetheless, similar religious freedom arguments appear in blasphemy cases. The responses to these arguments yet again reveal a marked

134 Interestingly, a few delegates did oppose religious tests because occasionally religious tests did interfere with conscience. Daniel Webster, for instance, stated,

It has been said that there are many very devout and serious persons-persons who esteem the Christian religion to be above all price-to whom, nevertheless, the terms of this declaration seem somewhat too strong and intense. They seem, to these persons, to require the declaration of that faith which is deemed essential to personal salvation .... There may, however, and there appears to be, conscience in this objection; and all conscience ought to be respected. I was not aware, before I attended the discussions in the committee, of the extent to which this objection prevailed.

$I d$. at 84. Josiah Hussey noted that Quakers could not swear to oaths and were therefore excluded as legislators. Therefore, he proposed allowing "any other person who cannot by the principles of his religious faith take an oath" to still serve as a representative. Id. at 86 (internal quotation marks omitted). These points typically came without further discussion, and therefore it is unclear how widely other delegates shared these sentiments.

135 See Sarah Barringer Gordon, Blasphemy and the Law of Religious Liberty in Nineteenth-Century America, 52 AM. Q. 682, 694 (2000); cf. LEONARD W. LEVY, BLASPHEMY: Verbal OfFense Against the SACRED, From Moses to SAlman Rushdie 401-23 (1993) (discussing early blasphemy cases).

136 Commonwealth v. Kneeland, 37 Mass. (20 Pick.) 206, 221 (1838).

137 See, e.g., Kneeland, 37 Mass. (20 Pick.) at 217, 219-20; People v. Ruggles, 8 Johns. 290, 291-92 (N.Y. Sup. Ct. 1811); Updegraph v. Commonwealth, 11 Serg. \& Rawle 394, 395 (Pa. 1824). 
preference for an individual liberty conception of religious freedom rather than one based on governmental neutrality.

The most famous nineteenth-century blasphemy case was an 1811 appeal of the conviction of John Ruggles, who allegedly had shouted in public that Jesus Christ was the illegitimate child of a promiscuous mother. ${ }^{138}$ Ruggles was convicted but appealed, arguing in part that New York's constitutional guarantee of religious freedom had abrogated the common-law crime of blasphemy. ${ }^{139}$ Ruggles never alleged that his religious beliefs compelled him to attack the prevailing Christian understanding of Jesus' virgin birth. Rather, he argued that the dissolution of an established church removed any state interest or authority in mediating religious arguments. ${ }^{140}$

Chief Justice James Kent delivered the opinion of the court: "The free, equal, and undisturbed enjoyment of religious opinion . . . is granted and secured; but to revile, with malicious and blasphemous contempt, the religion professed by almost the whole community, is an abuse of that right." 141 Later in the opinion he added,

[The state constitution's religious freedom provision] (noble and magnanimous as it is, when duly understood) never meant to withdraw religion in general, and with it the best sanctions of moral and social obligation, from all consideration and notice of the law. It will be fully satisfied by a free and universal toleration, without any of the tests, disabilities, or discriminations, incident to a religious establishment. ${ }^{142}$

Further clarifying the constitutionality of uneven treatment for various religious groups, Kent acknowledged that the crime of blasphemy applied only to anti-Christian remarks. ${ }^{143}$ Yet he dismissed Ruggles's insistence that the guarantee of free exercise "without preference or discrimination" meant that the state had to treat all inflammatory religious critiques equally:

Nor are we bound, by any expressions in the constitution, as some have strangely supposed, either not to punish at all, or to punish indiscriminately the like attacks upon the religion of Mahomet or of the grand Lama ... . [I]mputation of malice could not be inferred from any invectives upon superstitions equally false and unknown. ${ }^{144}$

According to Kent, Christianity was the religion of the people, and the state could therefore punish malicious attacks against it. ${ }^{145}$

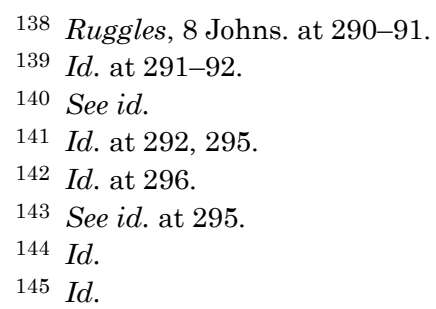


Constitutionally guaranteed religious freedom did not necessarily mean that all attacks on religion had to be treated equally. ${ }^{146}$

Other courts offered similar rationales for punishing blasphemy in spite of religious freedom clauses. "While our own free constitution secures liberty of conscience and freedom of religious worship to all," the Supreme Court of Pennsylvania held in Updegraph v. Commonwealth, "it is not necessary to maintain that any man should have the right publicly to vilify the religion of his neighbours and of the country. These two privileges are directly opposed." 147 Indeed, the court was careful to point out that blasphemy prosecutions did not punish individuals for their religious beliefs or practices. Writing for the court, Justice Duncan stated, "I do not think [blasphemy prosecutions] will be an invasion of any man's right of private judgment, or of the most extended privilege of propagating his sentiments with regard to religion, in the manner which he thinks most conclusive." 148 In short, the statements at issue in Updegraph were not a form of religious practice and therefore fell outside the bounds of constitutionally protected religious freedom. ${ }^{149}$

The Supreme Court of North Carolina's decision in State v. Jasper elaborates on the Updegraph court's distinction between liberty and license. ${ }^{150}$ The dispute arose when Henry Jasper attended a Baptist worship service and began "talking and laughing in a loud voice, and by then and there making divers ridiculous and indecent actions and grimaces." ${ }^{151}$ Rather than being indicted for nuisance, trespass, or breach of the peace, Jasper was charged and convicted for disturbing a religious service. ${ }^{152}$ On appeal, the justices considered the validity of Jasper's conviction for a seemingly novel offense. ${ }^{153}$

In upholding Jasper's conviction, the decision emphasized the importance of religious freedom under the state constitution, which stated that "all persons shall be at liberty to exercise their own mode of worship." 154 Writing for the court, Chief Justice Thomas Ruffin stated that this "provision does not profess to confer this right. It is worded, so as to show that it is acknowledged as pre-existing. The right is declared

146 Id.

14711 Serg. \& Rawle 394, 408 (Pa. 1824).

148 Id. at 409 .

149 Id.

15015 N.C. (4 Dev.) 323, 326-27 (1833). A short summary of this case also appears in Bernadette Meyler, The Equal Protection of Free Exercise: Two Approaches and Their History, 47 B.C. L. REV. 275, 308-09 (2006).

151 Jasper, 15 N.C. (4 Dev.) at 323.

152 Id. at 324 .

153 Id. at 325 .

154 N.C. Const. of 1776, art. XXXIV, reprinted in 5 The FEDERAL AND StATE ConstituTiOns, supra note 35 , at 2787, 2793. 
in the Bill of Rights to be a natural and unalienable right in all men." 155 Therefore, Ruffin declared,

The worship of God is not therein treated as indifferent, either in reference to the welfare of individuals, or the common interest. On the contrary, it is assumed to be a moral duty incumbent upon all men, and their highest privilege, as intelligent and accountable beings; a duty, that is best performed, both in honour to God, the comfort of each man and the peace and order of society, when that natural privilege is subjected to no legal restraints nor allowed to be disturbed by any person, either with or without the pretence of authority. ${ }^{156}$

Thus, Jasper's prosecution was not only constitutionally valid, but it actually furthered specific constitutional objectives. "[R] eligion needs no aid from the civil power," Ruffin wrote. ${ }^{157}$ Instead, religion needed only "the guaranty of its freedom from interruption, either by unjust laws or lawless force, or wantonness of individuals. Against the former, the Constitution is an express warrant, and by a necessary construction from that, as it seems to me, it equally forbids the latter." 158

The Jasper decision rests on the idea that the government has an affirmative duty to protect private rights by allowing individuals to seek redress in court when those rights are violated. ${ }^{159}$ In another religious disturbance case, Chief Judge William Cranch of the United States Circuit Court for the District of Columbia explained,

The principles upon which the disturbance of public worship becomes an offence at common law are these: Every man has a perfect right to worship God in the manner most conformable to the dictates of his conscience, and to assemble and unite with others in the same act of worship, so that he does not interfere with the equal rights of others. The common law protects this right, either by giving the party his private action for damages on account of the injury he has sustained; or if the violation of the right be directly, or consequentially injurious to society, by a public prosecution. ${ }^{160}$

155 Jasper, 15 N.C. (4 Dev.) at 324.

156 Id.

157 Id. at 326 .

158 Id.

159 Accord Corfield v. Coryell, 6 F. Cas. 546, 551 (C.C.E.D. Pa. 1823) (listing "[p]rotection by the government" among the "privileges and immunities of citizens in the several states" (internal quotation marks omitted)). Individuals' ability to seek redress in court for the invasion of their rights was understood in the nineteenth century to be part of their right to "protection of the laws." See Christopher R. Green, The Original Sense of the (Equal) Protection Clause: Pre-Enactment History, 19 GEO. MASON U. C.R. L.J. 1, 43-69 (2008) (listing nineteenth-century examples of the phrase "protection of the laws"); see also Earl A. Maltz, The Concept of Equal Protection of the Laws-A Historical Inquiry, 22 SAN DiEGo L. REV. 499, 499, 507-10, 522, 525 (1985) (linking the understanding of "protection of the laws" with the adoption of the Equal Protection Clause).

160 United States v. Brooks, 24 F. Cas. 1244, 1245 (C.C.D.C. 1834). 
In other words, because the right to religious freedom was individually held, the government was not the only one who could interfere with free exercise. Individuals also could violate that right, just as they could have done in the state of nature. As the Delaware Supreme Court observed in 1839, religious disturbances by private individuals "violated the constitutional right of every [congregant] to the free exercise of religious worship without molestation." 161 When that right was violated, the governmental duty to protect private rights justified prosecution of the offenders. ${ }^{162}$ The logic of this argument may seem odd, but in nineteenthcentury terms it made perfect sense because the unalienable right of free exercise was a natural right, not a guarantee of governmental neutrality.

It would be easy to dismiss nineteenth-century blasphemy cases and the Jasper decision as illegitimately infused with a parochial proChristian bias. What this Article hopefully demonstrates, however, is that regardless of any judicial predisposition to bend the law to advance Christianity (or punish dissenters), the decisions were at least consistent with prevailing views of religious freedom. The constitutional guarantee of an equally protected right to religious freedom was not considered a requirement that the government treat all religions equally. Rather, the government could not infringe upon-and sometimes it even had to affirmatively protect - the right of individuals to worship God according to their own consciences.

\section{Religious Assessments}

Blasphemy laws were not the only way that American states tried to support religion. Although most newly independent states eliminated any formal recognition of an established church, ${ }^{163}$ some states continued to levy taxes, often called religious assessments, for the support of ministers. ${ }^{164}$ Unlike religious tests for witnesses and legislators, these laws did not withhold certain privileges on the basis of religious belief, and generally all individuals had to pay the assessments regardless of their religious views. ${ }^{165}$ Nonetheless, while the collection of assessment taxes was neutral, the use of those taxes was not. Unless the law provided an exemption, assessment taxes supported a minister from the established church, or a minister preferred by the majority of local

161 State v. Townsend, 2 Del. (2 Harr.) 543, 547 (1839); see also Carl Zollmann, Disturbance of Religious Meetings in the American Law, 49 AM. L. REV. 880, 880-81 (1915) (containing more information about past laws protecting against private infringements on free exercise).

162 Townsend, 2 Del. (2 Harr.) at 547.

163 Wilson, supra note 33 , at 754 .

164 Id.

$165 I d$. 
taxpayers. 166 Thus, religious dissenters often vehemently opposed assessment laws and argued instead for governmental neutrality toward religion. Perhaps not surprisingly, these dissenters frequently invoked religious liberty.

Early nineteenth-century debates in Massachusetts illustrate the arguments on both sides of the assessments controversy. Massachusetts law provided that dissenters could designate their religious taxes for the support of their own pastors. ${ }^{167}$ In 1810, the state's Supreme Judicial Court considered a case in which a minister from a minority sect known as the Universalists claimed a right to public funds pursuant to that statute. 168 Universalists, however, were only beginning to view themselves as a distinct sect separate from their Congregationalist forbearers. ${ }^{169}$ More importantly, the legislature had not yet recognized their incorporation, which was a precondition for receiving funds under the assessment law.170 Undeterred by this legislative inaction, the Universalist minister argued that the court should broadly construe the assessment law's exemption provision: "[W] hen a man disapproves of any religion, or of any supported doctrines of any religion," the minister argued, "to compel him by law to contribute money for public instruction in such religion or doctrine, is an infraction of his liberty of conscience ...." ${ }^{171}$

The Supreme Judicial Court rejected the minister's religious liberty argument. ${ }^{172}$ Writing for the court, Chief Justice Theophilus Parsons explained,

166 Id. at 756.

167 See An ACT providing for the public Worship of GOD, and other Purposes therein mentioned, and for repealing the Laws heretofore made relating to this Subject (1800), in 3 The Perpetual Laws of the Commonwealth of MassachusetTs 105, 106 (I. Thomas \& E.T. Andrews eds., 1801). The law provided,

That when any person taxed in any such tax or assessment voted to be raised as aforesaid, for the purposes aforesaid, being at the time of voting or raising any such tax or assessment of a different sect or denomination from that of the corporation, body politic or religious society by which said tax was so assessed, shall request, that the tax set against him or her, in the assessment made for the purposes aforesaid, may be applied to the support of the public teacher of his own religious sect or denomination; such person, procuring a certificate signed by the public teacher on whose instruction he usually attends, and by two other persons of the society of which he usually attends, and by two other persons of the society of which he is a member (having been specially chosen a committee to sign said certificate) .... Id. at 106.

168 Barnes v. Inhabitants of the First Parish in Falmouth, 6 Mass. (6 Tyng) 401, 401-03 (1810).

169 Id. at 402.

$170 \mathrm{Id}$.

171 Id. at 408.

172 Id. 
When it is remembered that no man is compellable to attend on any religious instruction, which he conscientiously disapproves, and that he is absolutely protected in the most perfect freedom of conscience in his religious opinions and worship, the first objection seems to mistake a man's conscience for his money, and to deny the state a right of levying and of appropriating the money of the citizens, at the will of the legislature, in which they all are represented. ${ }^{173}$

According to Parsons, "The great error lies in not distinguishing between liberty of conscience in religious opinions and worship, and the right of appropriating money by the state. The former is an unalienable right; the latter is surrendered to the state, as the price of protection." 174 Religious dissenters may not wish to fund the propagation of majority religious views, he remarked, but paying taxes does not infringe upon their free exercise of religion. ${ }^{175}$

Assessment debates at the 1820 Massachusetts Constitutional Convention reflect similar understandings of religious liberty. In a lengthy discussion of religious freedom, most delegates strongly rejected the notion that religious taxes infringed upon the rights of conscience. ${ }^{176}$ George Blake's comment exemplified the delegates' frequent retorts: "The question was not a question of conscience, but of pounds shillings and pence. There was no injunction in [the assessment law] to attend at any particular place of public worship: every man might attend where he pleased."177 In other words, liberty of conscience is unalienable, but governmental power to distribute taxes in favor of certain religious groups does not implicate that basic freedom. Dissenters objected to this favoritism, but the assessment law left them free to practice their own religion without interference.

\section{E. The 1821 New York Convention}

With a sizeable Catholic population ${ }^{178}$ and a thriving community of religious dissenters in the western part of the state, ${ }^{179}$ New York's history is full of debates about religious liberty. In 1811, for instance, New York's highest court upheld the blasphemy conviction of John

173 Id. Parsons continued, "[I]f any individual can lawfully withhold his contribution, because he dislikes the appropriation, the authority of the state to levy taxes would be annihilated; and without money it would soon cease to have any authority." Id. at 409.

174 Id.

175 Id. at $417-18$.

176 Boston DAILY ADVERTISER, supra note 126, at 167.

177 Id.

178 See generally Jason K. Duncan, Citizens or Papists?: The Politics of AnTiCATHOLICISM IN NEW YoRK, 1685-1821, at xviii (2005).

179 See generally Whitney R. CROSS, THE BURNED-Over District: THE Social AND INTELlECTUAL History OF ENTHUSIASTIC RELIGION IN WESTERN NEW YORK, 1800-1850, at 3-13 (photo. reprint 1981) (1950). 
Ruggles for disparaging Jesus' virgin birth. ${ }^{180}$ Only nine years later, the court again handed down a widely publicized case, this time affirming the state's authority to exclude atheists and Universalists from testifying in court. ${ }^{181}$ In the intervening years, lower courts decided two prominent cases addressing the right of individuals to receive religious exemptions from common-law evidence rules. ${ }^{182}$

Early proponents of neutrality usually accepted the premise of the individual liberty theory but interpreted that theory broadly so as to incorporate neutrality principles. Oliver Ellsworth, for instance, argued that individuals should not be required to divulge their religious beliefs, and therefore, laws relying on such statements were per se unconstitutional. ${ }^{183}$ Debates at the 1821 New York Constitutional Convention, however, demonstrate that the two theories of religious freedom occasionally collided, with neutrality advocates wanting to displace rather than expand upon the individual liberty approach. In particular, some neutrality proponents hinted that accommodations for religious scruples constituted a religious preference inconsistent with the equal right of free exercise.

Controversy in the 1821 Constitutional Convention first surfaced over whether Quakers should receive exemptions from militia service and, if so, whether they should have to pay an equivalent fee. ${ }^{184}$ State legislator Erastus Root, the champion of the neutrality position, argued against accommodations for Quakers. "The consequence" of such accommodations, he argued, "is, that the state is overrun with Quakers-both wet and dry."185 Instead, Root wanted to "amend the constitution, as to bring them up to the work. He would place them all on the same muster roll." 186 Root then took aim at the government's lack of religious neutrality, proposing a constitutional guarantee that "[t]he

180 People v. Ruggles, 8 Johns. 290, 291, 298 (N.Y. Sup. Ct. 1811).

181 See Jackson, ex dem. Tuttle v. Gridley, 18 Johns. 98, 99-100, 106 (N.Y. Sup. Ct. 1820).

182 People v. Smith (N.Y. Oyer \& Terminer 1817), reprinted in 1 AMERICAN STATE

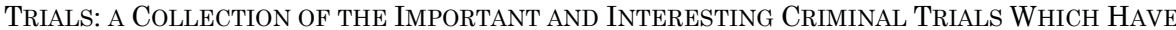
TAKen Place in the United States from the Beginning of OUR Government to the PRESENT DAY 779, 784 (John D. Lawson ed., 1914) (rejecting a similar right of exemption for Protestants because penance is not part of their religious practice); People v. Philips (N.Y. Ct. Gen. Sess. 1813), reprinted in William Sampson, The Catholic Question in AMERICA 5, 9-10 (Edward Gillespy ed., 1813) (upholding the right of a Catholic priest to an exemption from testifying about confessional statements); see also Walsh, supra note 18, at 39-40 (containing thorough discussions of these cases).

183 Ellsworth, supra note 121, at 522-23.

184 Nathaniel H. Carter et al., Reports of the Proceedings and Debates of THE Convention of 1821, Assembled For the PuRPose of AMENDing the Constitution OF THE STATE OF NEW YORK 462 (1821).

185 Id.

$186 I d$. 
judiciary shall not declare any particular religion, to be the law of the land; nor exclude any witness on account of his religious faith." 187 This latter proposal attempted to repudiate the state supreme court's recent decisions in Ruggles and Gridley. ${ }^{188}$

Root's proposals met a cool reception in the convention. Chancellor James Kent replied that blasphemy was punishable

not because christianity was established by law, but because christianity was in fact the religion of this country, the rule of our faith and practice, and the basis of the public morals. . . The court never intended to interfere with any religious creeds or sects, or with religious discussions. ${ }^{189}$

According to Chancellor Kent, "[t]he constitution had declared that there was to be "no discrimination or preference in religious profession or worship.' But Christianity wos, in fact, the religion of the people of this state, and that fact was $(1)$ principle of the decision." ${ }^{190}$ Rufus King agreed. "While all mankind are by our constitution tolerated, and free to enjoy religious profession and worship within this state," the senator and former delegate at the Federal Constitutional Convention declared, "the religious professions of the Pagan, the Mahomedan, and the Christian, are not, in the eye of the law, of equal truth and excellence.... While the constitution tolerates the religious professions and worship of all men, it does more in behalf of the religion of the gospel." ${ }^{191}$ In other words, all were equally free to practice their own religions, but the government could still treat religions differently so long as there was no interference with religious beliefs and worship.

The delegates eventually voted by a margin of sixty-two to twentysix in favor of a provision stating, "It shall not be declared or adjudged that any particular religion is the law of the land." 192 Far from being a victory for Root, however, many delegates viewed the amendment as purely symbolic. ${ }^{193}$ Chancellor Kent voted for the measure, later noting that "[i]t was perfectly harmless, and might be a security. No judge would think of making any particular religion a part of the law of the land." 194 For Chancellor Kent, the provision guaranteed non-

187 Id.

188 See id.

189 Id. at 463. Chancellor Kent continued, "Such blasphemy was an outrage upon public decorum, and if sanctioned by our tribunals would shock the moral sense of the country, and degrade our character as a christian people." Id.

$190 I d$. at 575.

191 Id.

192 Id. at 464

193 Id. at 465

194 Id. Chancellor Kent "repeated that if he were to decide to-morrow, in a case similar to the one referred to ... he should give such a decision as had been read in debate yesterday." Id. 
establishment rather than strict governmental neutrality. Root then reintroduced his proposal to allow witnesses to testify irrespective of their religious faith. ${ }^{195}$ One delegate supported the motion, stating that "we should be above such prejudices, and act on the broad principles of liberty." 196 After several comments regarding the efficacy of oaths, the delegates voted against Root's proposal by a vote of ninety-four to eight. ${ }^{197}$

Still stinging from defeat, Root returned several days later to his fight against religious exemptions for Quakers. ${ }^{198}$ The delegates primarily wrangled over how to determine whether conscientious objectors were sincere in their religious scruples. Responding to Root's argument that many people were only pretending to harbor conscientious scruples, Judge Ambrose Spencer, author of the recent testimonial-exclusion opinion in Gridley, stated that "we have reason to think [Quakers are] very sincere. They abstain from the use of sugar and molasses, and all other articles which are produced by the means of slavery." 199 Judge Spencer continued,

These men are also abridged in the right of suffrage; by neglecting to do military duty, many of them will lose the privilege of voting; and there is not the least probability that men will turn Quakers merely to get clear of military duty. This was a subject which might be safely left to the legislature to determine; and it would certainly be much more appropriate for that body to decide the question, than for this Convention, under existing circumstances, to do it. 200

Not everyone agreed with Judge Spencer's optimistic appraisal. ${ }^{201}$ There was broad consensus, however, that the rights of conscience should be protected for genuine conscientious objectors. ${ }^{202}$ One delegate noted, If scruples of conscience are ever acknowledged to be sincere, why should they now be violated, and a whole religious sect be arraigned for hypocrisy? Were they not as likely to be as honest and sincere in their professions, as any other class of Christians; and should we act upon the supposition that all religious professions were hypocritical and false?203

After a colloquy between several delegates regarding "the rights of conscience," the convention voted to exempt Quakers, although it also

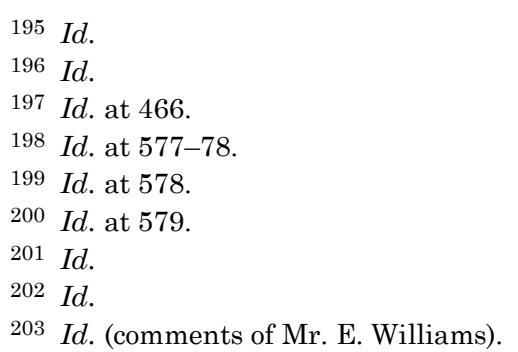


provided for an equivalent to be levied "according to the expense, in time and money, of an ordinary able-bodied militia-man." 204

\section{CONCLUSION}

New York's elder jurists, including Kent, Spencer, and King, prevailed over Root in their fight to maintain an individual liberty view of religious freedom without simultaneously recognizing a broader right against governmental classifications based on religious beliefs. Meanwhile, Root and his supporters never explicitly denounced an individual liberty conception of religious freedom. They merely questioned the sincerity of conscientious objectors. Yet their simultaneous attacks on testimonial exclusions, blasphemy prosecutions, and legislative accommodations exposed the priority these delegates placed on governmental neutrality. In subsequent decades, neutrality arguments became more prevalent and well-accepted. ${ }^{205}$ States gradually removed testimonial exclusion rules, test oaths, and religious assessments. ${ }^{206}$

Although the Supreme Court has exalted neutrality as the core of religious liberty, early nineteenth-century debates reveal that this focus on neutrality has not always prevailed. In fact, by viewing religious freedom as an unalienable natural right rather than a governmentcreated right, most early jurists and legislators understood religious freedom primarily in terms of individual liberty. As neutrality cases demonstrate, they considered infringements on religious practice to be a necessary component of a free exercise claim. Governments routinely classified individuals on the basis of religious belief, but these laws withstood constitutional scrutiny because they did not directly interfere with religious practices. When neutrality proponents attacked these classifications by invoking religious freedom, the usual response was a terse reminder that the unalienable right of conscience did not remove religion from the purview of legislative power.

To be sure, states also recognized nascent principles of governmental neutrality. The federal and state establishment clauses, for example, circumscribed governmental power over religion. The key thing to keep in mind, though, is that while state establishment clauses gradually moved further toward a neutrality-based view of proper governmental powers, the unalienable right of free exercise continued to

204 Id. at 579-80 (internal quotation marks omitted). There is no recorded vote regarding the exemption for Quakers. The vote was eighty-eight to twenty-eight in favor of retaining a provision for militia service equivalents. Id.

205 For one story of this change, see Kurt T. Lash, The Second Adoption of the Establishment Clause: The Rise of the Nonestablishment Principle, 27 ARIZ. ST. L.J. 1085, 1100-05 (1995).

206 Id. at 1117. 
protect individuals. As John Witte writes, "Where general laws and policies did intrude on the religious scruples of an individual or group, liberty of conscience demanded protection of religious minorities through exemptions from such laws and policies. This was the heart of the meaning of religious toleration." ${ }^{207}$ This did not, of course, mean that all individuals became judges of their own causes with respect to religious exemptions. Government still had to decide whether religious objections were sincere and whether providing exemptions would disturb the peace. At its core, however, religious freedom protected the unalienable, individual right to worship God according to the dictates of conscience.

In 1978, the Supreme Court considered a challenge to Tennessee's prohibition against ministers serving as legislators. ${ }^{208}$ The Court unanimously struck down the rule, which had existed in Tennessee's constitution since 1796. ${ }^{209}$ Not surprisingly, nearly all the justices thought the prohibition violated the Free Exercise Clause because it discriminated against religion. ${ }^{210}$ Yet, oddly enough, Justice Byron White disagreed. The majority, he argued, "fails to explain in what way [the plaintiff minister] has been deterred in the observance of his religious beliefs. Certainly he has not felt compelled to abandon the ministry as a result of the challenged statute, nor has he been required to disavow any of his religious beliefs." 211 For that reason, Justice White was "not persuaded that the Tennessee statute in any way interferes with [the minister's] ability to exercise his religion as he desires," and therefore the provision did not offend the Free Exercise Clause. ${ }^{212}$ Instead, Justice White would have overturned Tennessee's ministerial exclusion as a violation of the Equal Protection Clause. ${ }^{213}$

Justice White's interpretation of the Free Exercise Clause embodies an older understanding that has long since fallen out of favor. When assessing religious freedom claims, courts no longer consider whether a law actually interferes with an individual's religious beliefs or

207 WiTte, supra note 33, at 44. Witte continues, "Whether such exemptions should be accorded by the legislature or by the judiciary and whether they were per se a constitutional right or simply a rule of equity - the principal bones of much scholarly contention today - the eighteenth-century sources do not dispositively say." Id. Similarly, in this paper, I focus on the meaning of free exercise-not how the founding generation anticipated that concept to become operational.

208 McDaniel v. Paty, 435 U.S. 618, 620 (1978) (plurality opinion).

209 Id. at $621,629$.

210 See id. at 629; id. at 630 (Brennan, J., concurring); id. at 642 (Stewart, J., concurring).

211 Id. at 643-44 (White, J., concurring).

$212 I d$. at 644.

213 Id. at 646. 
worship. ${ }^{214}$ Rather, governmental neutrality has taken over as the preeminent concern of the Free Exercise Clause. This neutrality-based understanding of religious freedom is not inherently incompatible with the individual liberty theory. Indeed, the comments of Oliver Ellsworth and James Prince illustrate that neutrality itself originated, at least in part, as an extension of individual liberty principles. In the years since, however, Supreme Court jurisprudence has lost touch with this original understanding. Perhaps not surprisingly, exalting neutrality as the core value of religious freedom has colored how we think about whether religious exemptions fall within the purview of free exercise. From a neutrality-centered perspective, the idea of granting religious exemptions seems expansive or perhaps even radical.

Yet the founding generation did not operate under these assumptions. Far from being radical, exemptions were standard practice in the late eighteenth and early nineteenth centuries. Meanwhile, governmental neutrality was the more expansive theory of religious liberty and a greater threat to the status quo. Prolific, yet largely neglected, neutrality debates help clarify this original understanding of free exercise as an unalienable right rather than as a religion-specific precursor to modern equal protection principles.

214 Emp't Div. v. Smith, 494 U.S. 872, 881 (1990); see also Church of the Lukumi Babalu Aye, Inc. v. City of Hialeah, 508 U.S. 520, 533 (1993) (“[A] law targeting religious beliefs as such is never permissible ....”). 